تحليل عددى هيدروليك جريان در يك رودخانه مخروطافكنهاى با مدل CCHE2D (مطالعه موردى: حدفاصل يل سودجان تا اور گان رودخانه ديمه)

\author{
افشين هنربخش'، محمد فتحى بَ* و محمد رستمى '

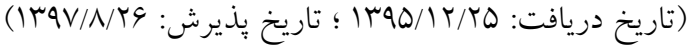

جكيده

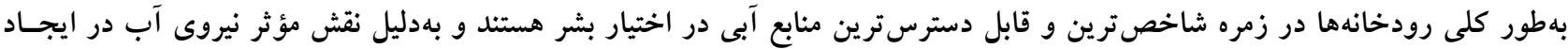

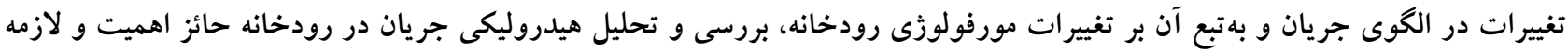

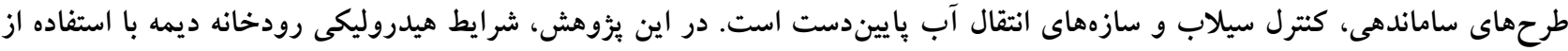

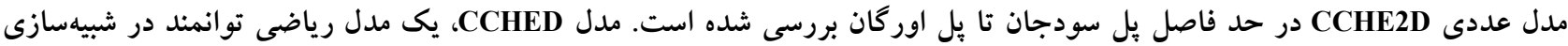

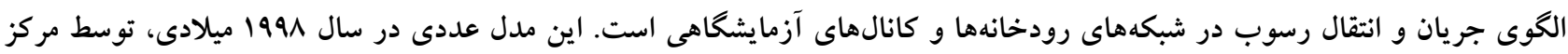

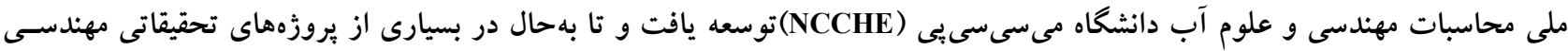

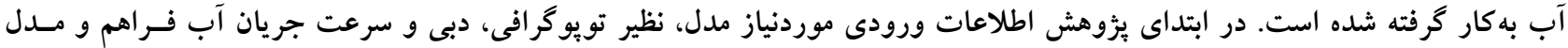

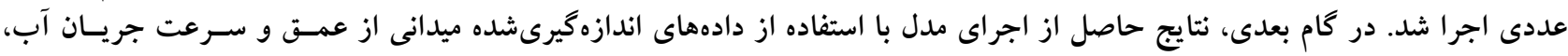

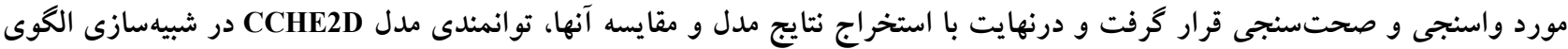
جريان تأييد شد.

وازههاى كليدى: الكوى جريان، رودخانه، صحتسنجى، مدل CCHE2D، مورفولوزى

\footnotetext{
1. أشكده منابع طبيعى و علوم زمين، دانشكاه شهركرد

r. يزووهكده حفاظت خاك و آبخيزدارى كشور، تهران
}

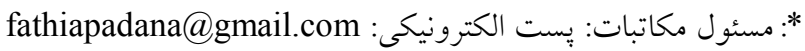




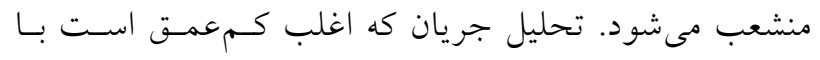

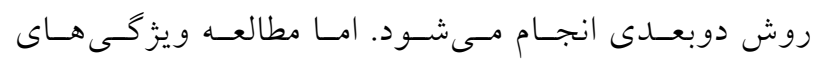

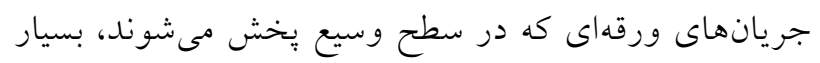

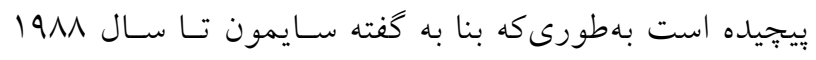

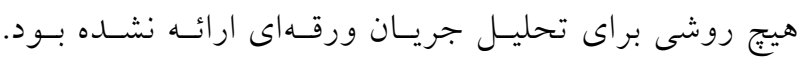

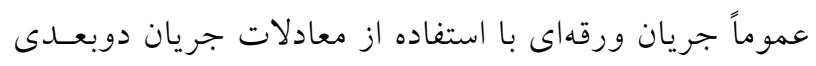

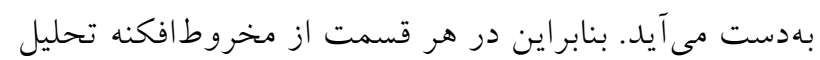

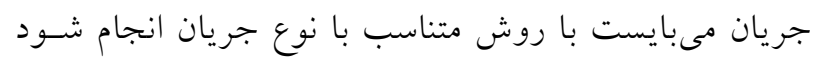

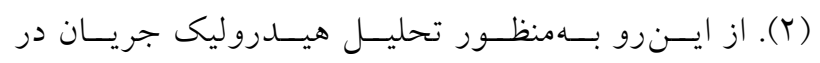

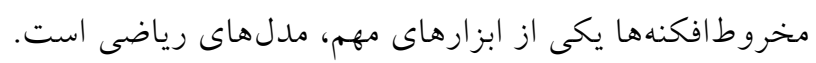

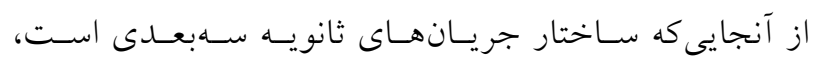

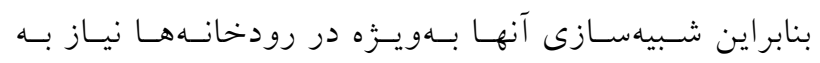

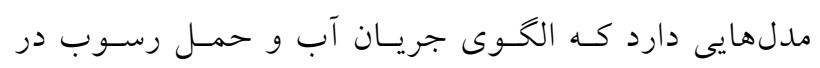

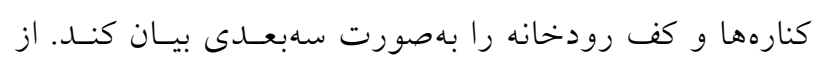

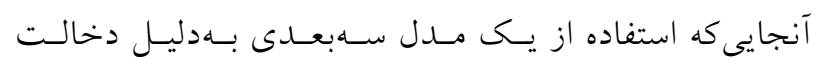
فرسايش كنارهاى و بِارامترهـاى دخيـل (مسؤثر) در آن نسـبتاً

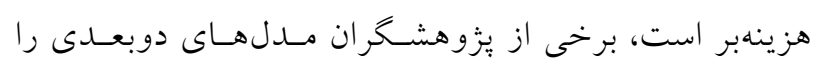

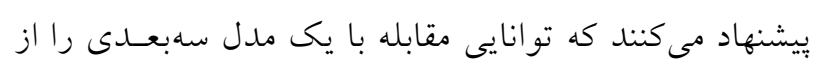

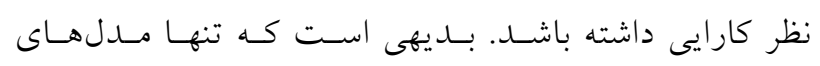

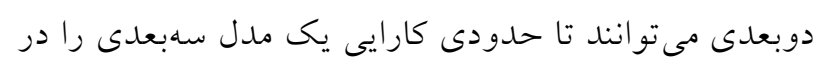

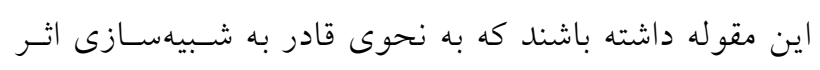

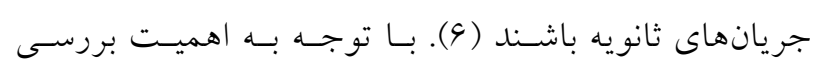

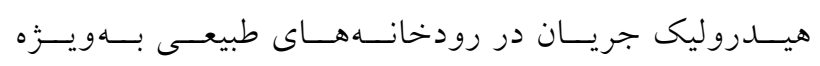

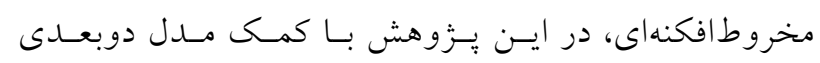
CCHE2D

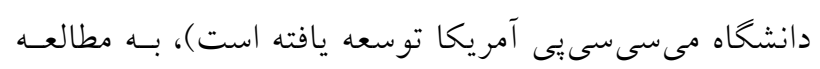

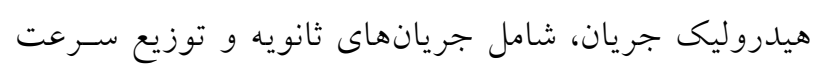

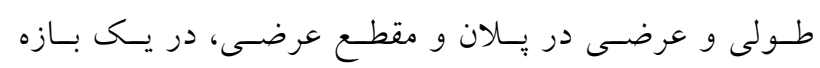
مخروطافكنهاى از رودخانه ديمه يُرداخته شد. براى تحليل فرايندهاى هيدروديناميك جريـان در رودخانسه،

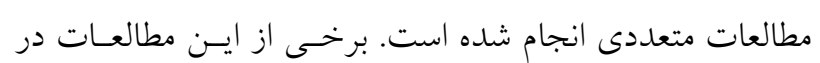
غالب مدلهاى عددى بهشرح زير است:

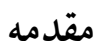

رودخانهها تحت تأثير عوامل طبيعى و يا دخالتهاى انسانى

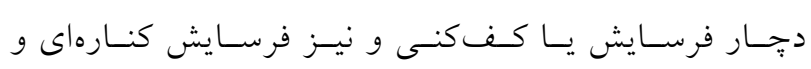

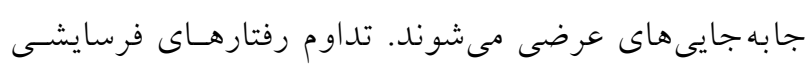

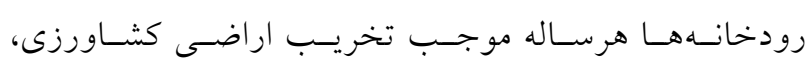

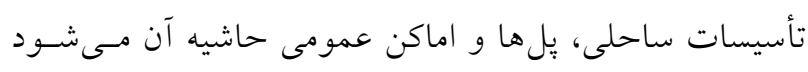

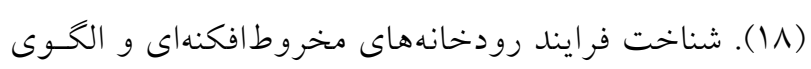

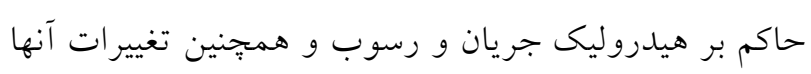

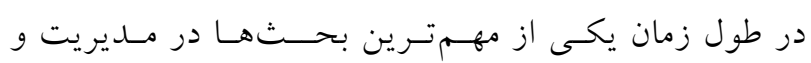

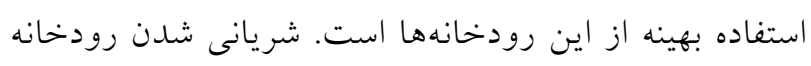

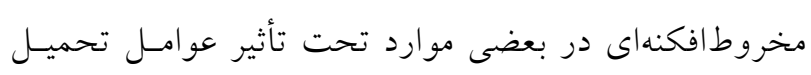

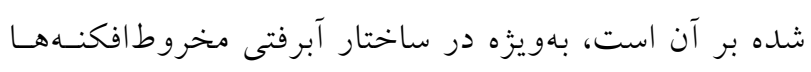

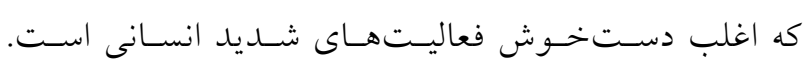

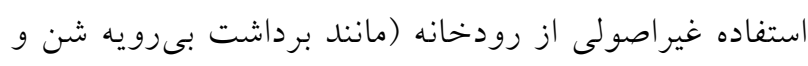

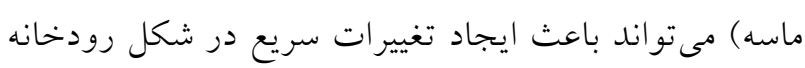

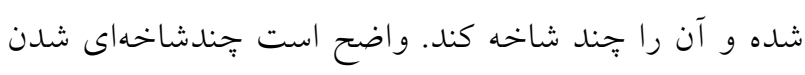

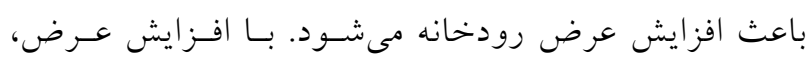

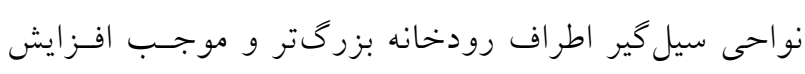

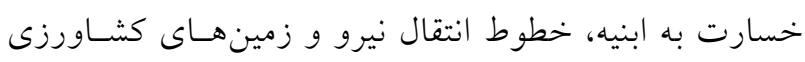

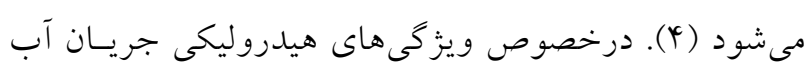

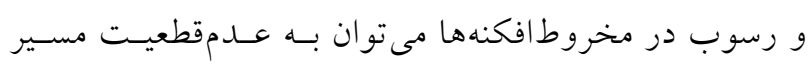

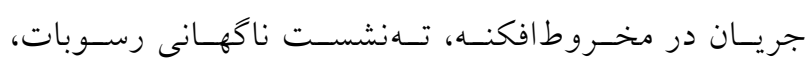

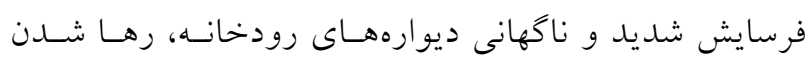

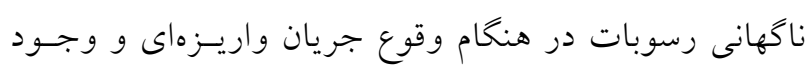

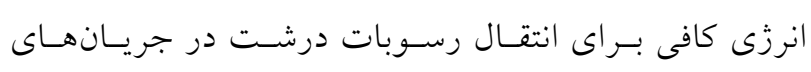

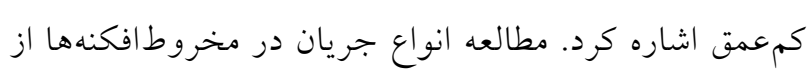

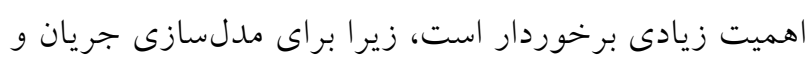

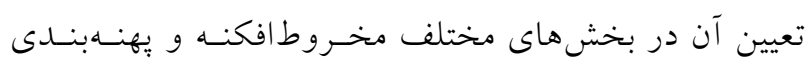

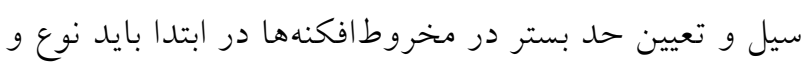

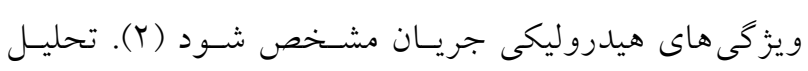

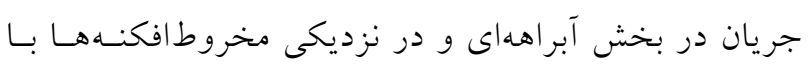

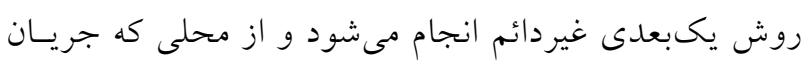




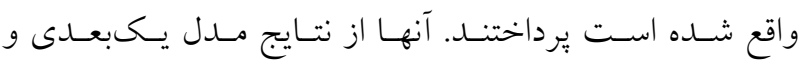
دوبعـدى MIKE FLOOD بـراى بـراورد خسـارت درمحسيط

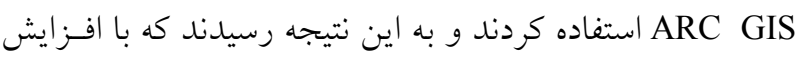

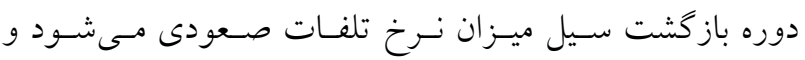
ييشنهاد دادند كه راهكارى مناسب براى كـاهش خسـارت سـيل

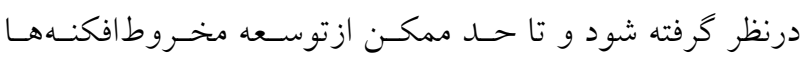

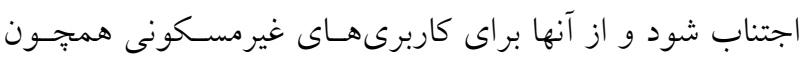
يارك، فضاى تفريحى وكشاورزى استفاده شود.

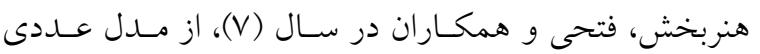
دوبعدى CCHE2D براى شبيهسازى الكوى جريان در بازهاى از

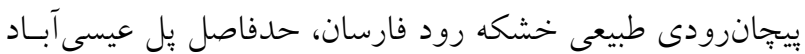
تا كارخانه شنشويى گوجان در اسـتان جهارمحسال و بختيـارى، استفاده كردند و به اين نتيجه رسيدند كه مدل، قابليـت مطلـوبى

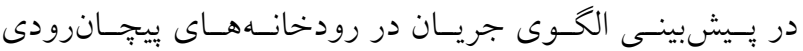

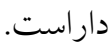
خسروى (Q) )، از مـدل عـددى دوبعـدى CCHE2D بـــاى شبيهسازى الكوى جريان و رسـوب در بــازماى از يِيجـانرودى

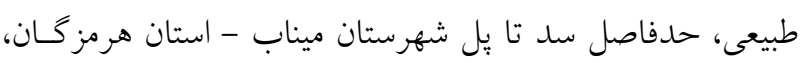

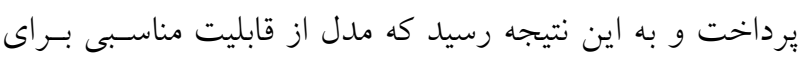

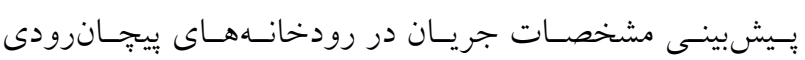
برخوردار است. جيا و همكاران (r||)، به شبيهسازى عـددى جريـان، حمـل رسوب، تغييرات تويو گرافى بستر و سـازههـاى رودخانـهاى، در

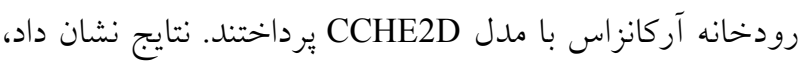

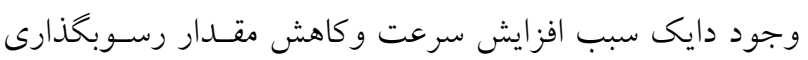

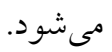
جيا و ونخ (4) (1)، يك مدل دوبعدى هيدروديناميك و حمل

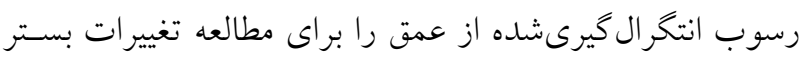
و جريان در كانالهاى روباز توسعه دادند. اين مـدل CCHE2D

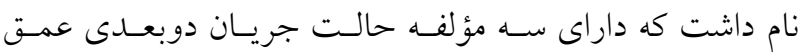
ميانكين، حالت حمل باركف و حالـت شـبيهسـازى تـراز بسـتر است. در اين مدل، معادلات گشتاور دوبعدى انتخر ال كيرىشـــه
وفايى منش و خرسندى (T9)، در يزوهشى با عنـوان تحليـل يكبعدى جريان در رودخانهاى شريانى و تعيين بستر و حريم آنها بـه بررسى موضـوع در رودخانسه مخــروطافكنـهاى رودان

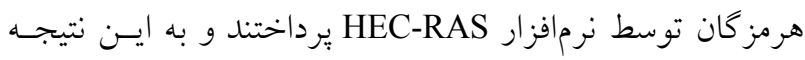

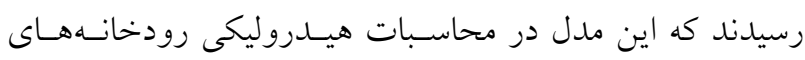

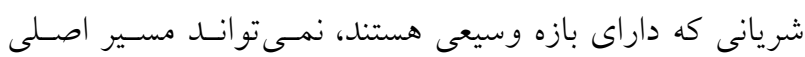

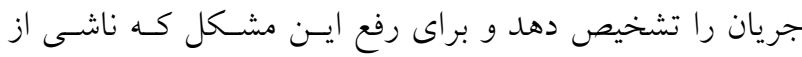

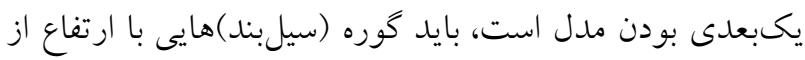

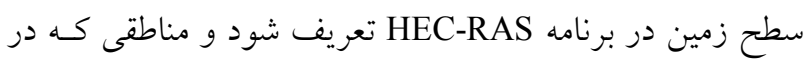
مسير جريان قرار ندارند، حذف شوند.

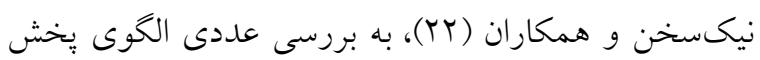
سيلاب در مخـروطافكنـه رودخانـه جامـاش اسـتان هرمز كـان

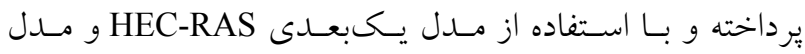
يكبعدى - دوبعدى MIKE FLOOD و درنظر كرفتن بارامترهـيى ونسي

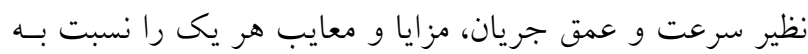

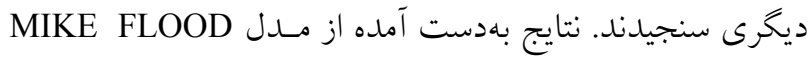
در محيطهاى سيلابدشتى و مخروطافكنهاى كه بِخش جريـان

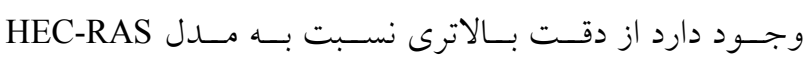
برخوردار بوده و به نسبت ارجحيت دارد.

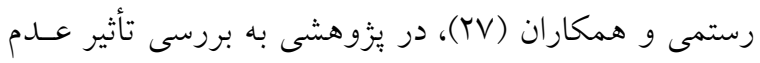

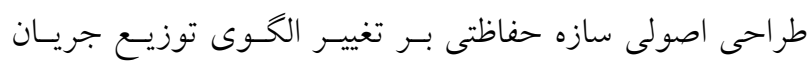

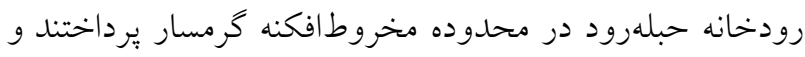

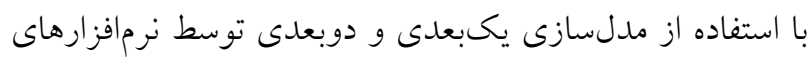

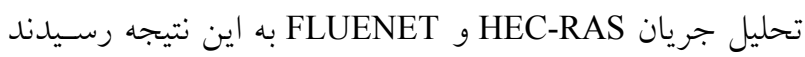
كه عدم طراحى اصولى سـازه حفـاظتى كنـاره رودخانـه، بــدون

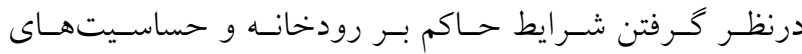

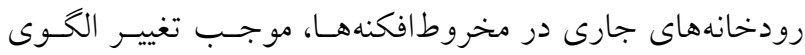

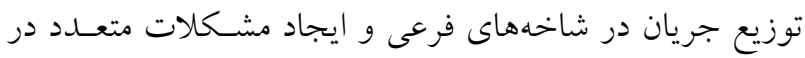
پاييندست محدوده مطالعاتى شده است. نيكرو و همكاران (YI)، به بررسى ميـزان خسـارات جـانى لئى

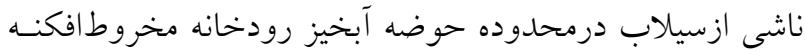

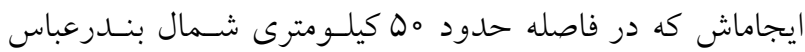


صفرمعادلهاى مقايسه كردند. بر اساس مقايسه، اين نتيجه حاصل

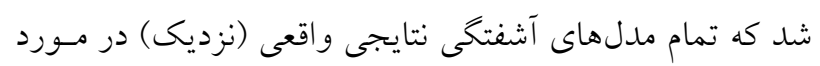

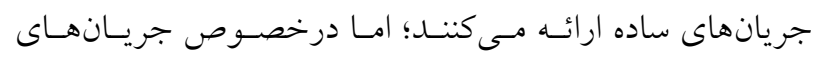

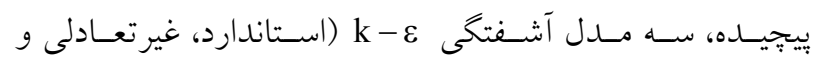
RNG

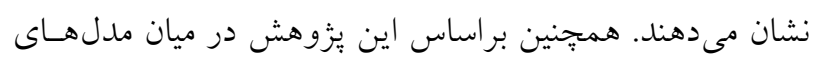

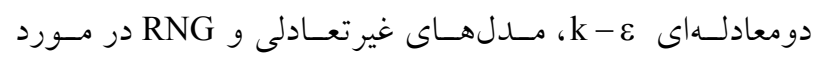
جريانهاى جرخشى، نتايج بهترى ارائه مى كنند.

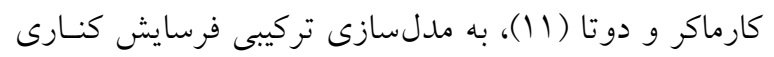

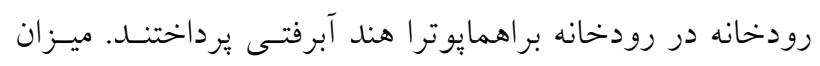

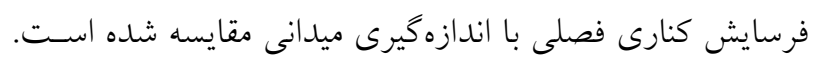

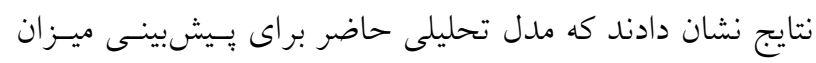

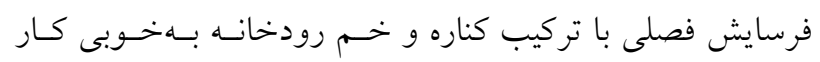
مى كند.

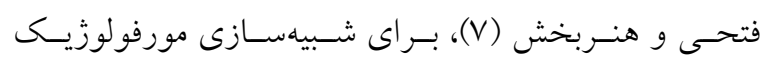

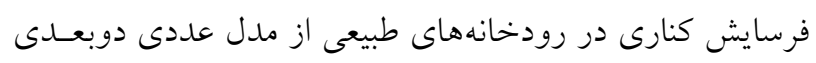

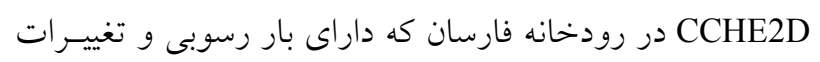

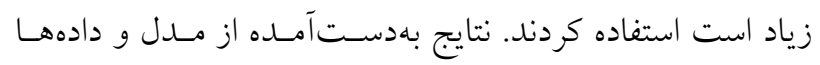
قابليت مدل CCHE2D براى شبيهسازى فرسايش كنارى در اين رودخانه را نشان داد. كمانبدست و همكاران (11)، براى براورد رسوب رودخانسه

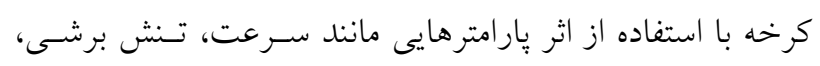

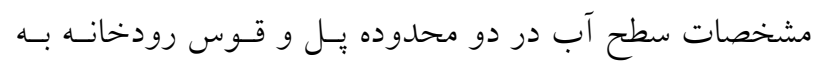

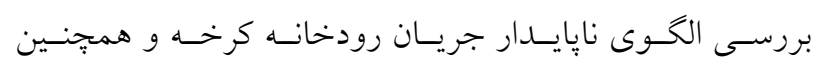

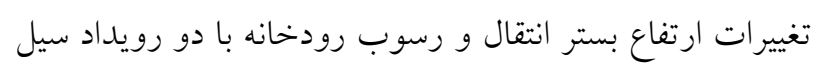

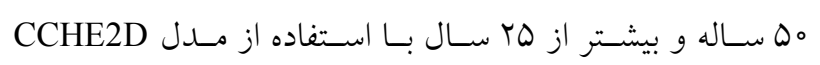

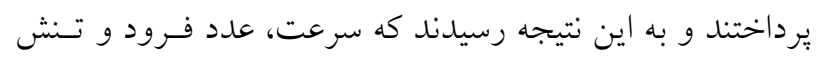

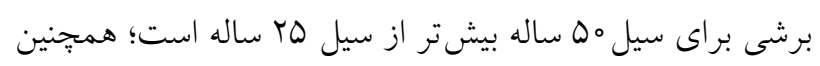

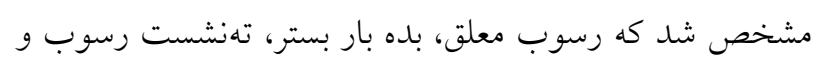
فرسايش براى سيل •ه ساله بيشتر از سيل ها ماله سله است.

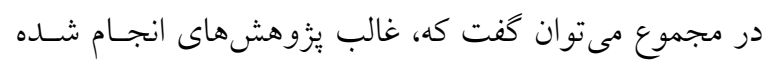

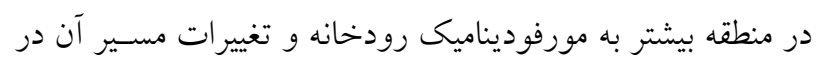

از عمق براى جريان آشفته در يكى سيستم مختصـات كـارتزين

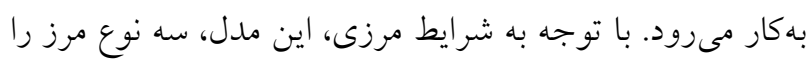

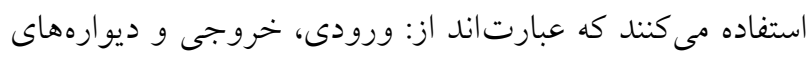

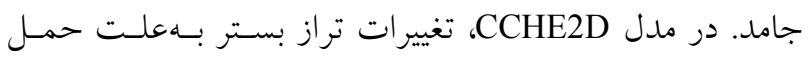
باركف و اثر جريان ثانويه روى فرايند حمل در كانالهاى يميجان

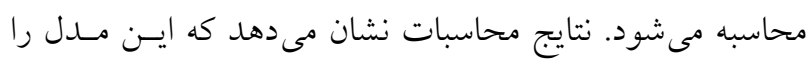

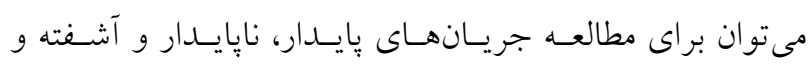

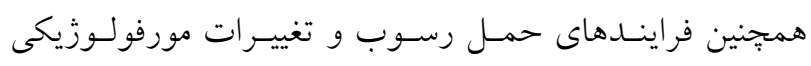

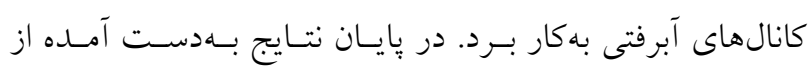

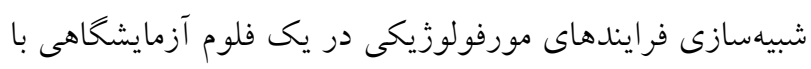

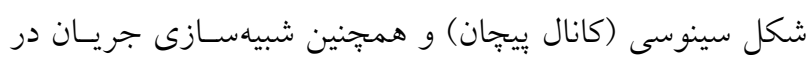

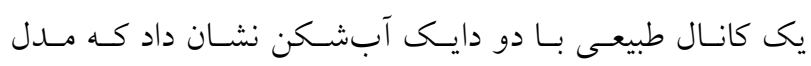
CCHE2D

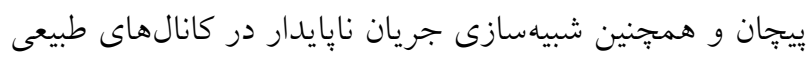

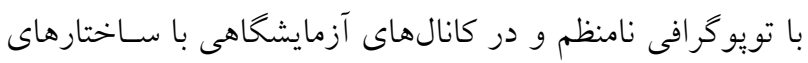
هيدروليكى مشابه موارد طبيعى را دارد.

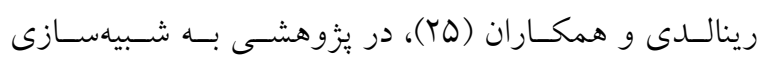

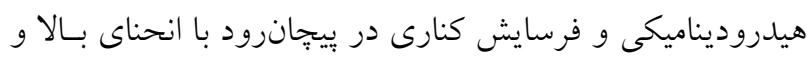
بستر درشتدانه رودخانه سسينادر مركز ايتاليا يرداختنـد، نتـايج وديج

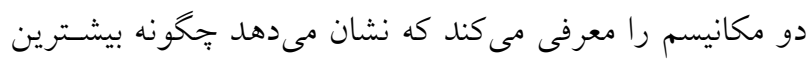

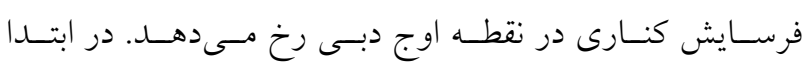

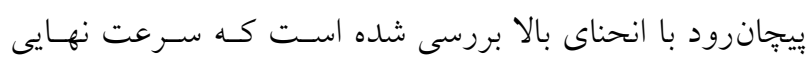

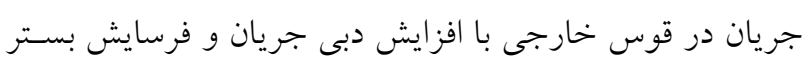

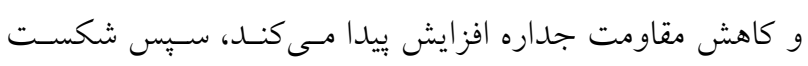

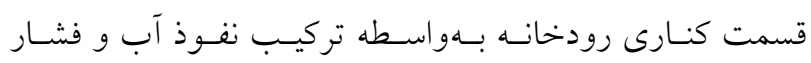

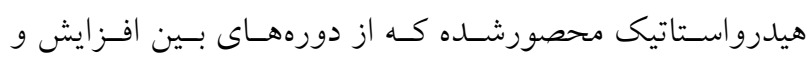

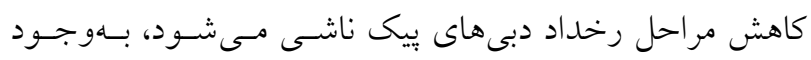
مى آيد. وو و ونخ (م) (ب)، در مطالعات خود به شبيه سازى جريـان و

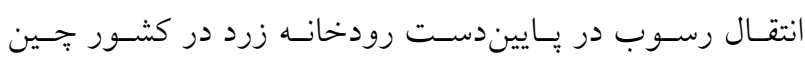

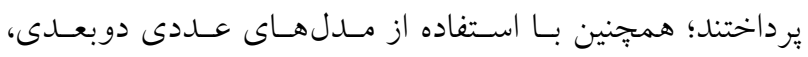

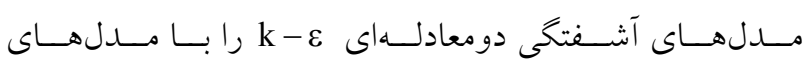




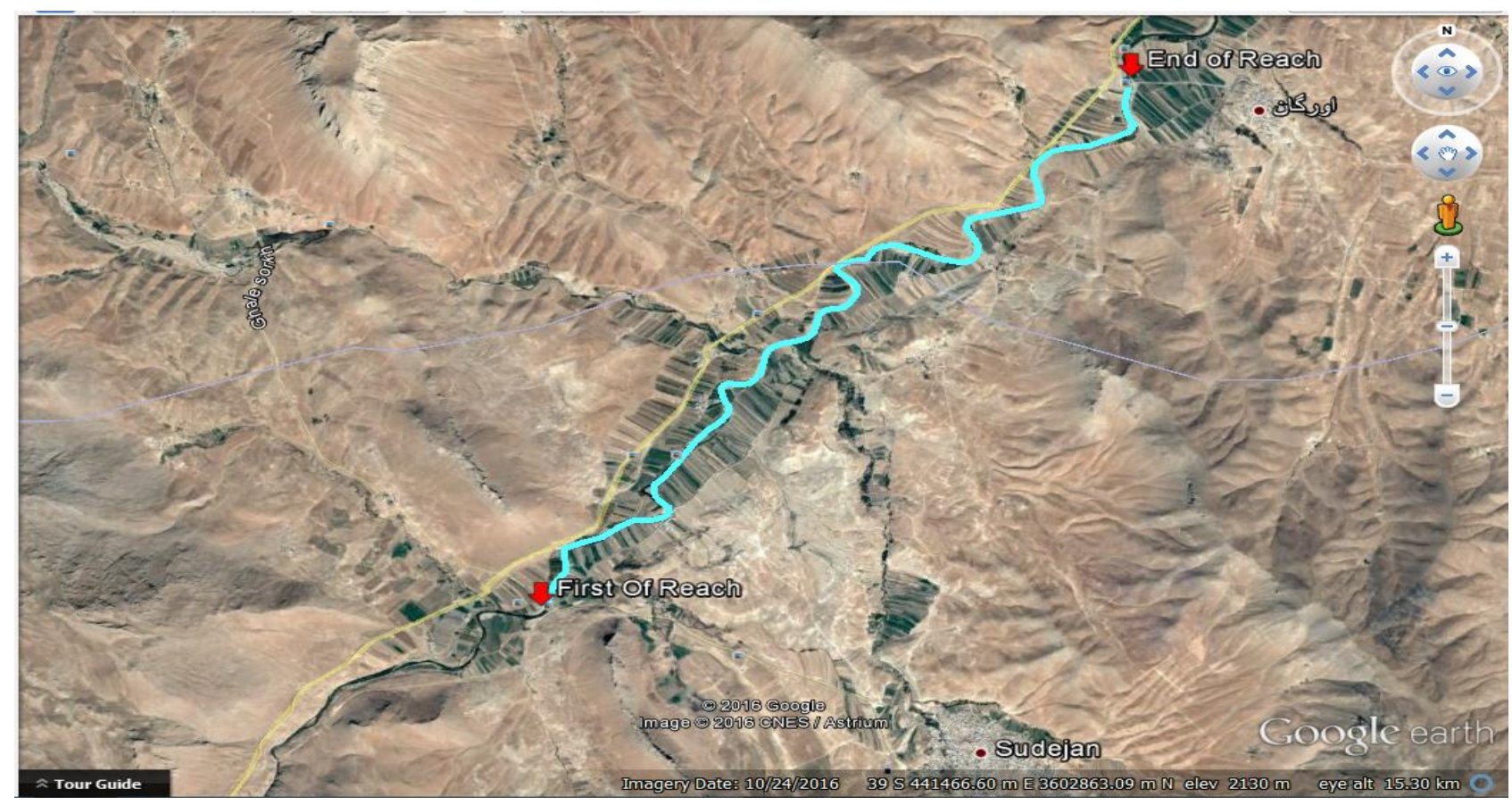

شكل ا. نمايى از موقعيت بازه مكانى مورد مطالعه

نشان مى نهد. اين رودخانسه در نزديكسى شـهر جهلكرد و قبل از الحاق رودخانهاى فرعى آبخره و خروجىى

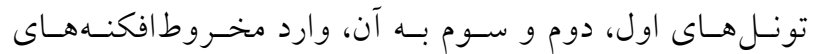
متعددى شـده و شـريانى مسىشـود. عـرض رودخانسه در ايسن

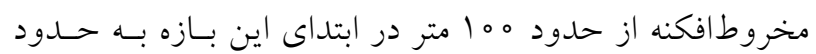

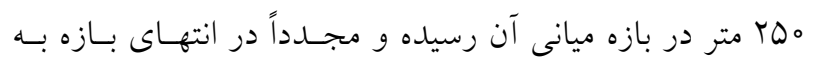
شر ايط طبيعى بـازمى گـردد (شـكل (1). باركـذارىهـاى انجـام

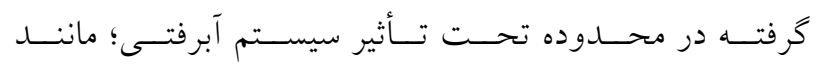

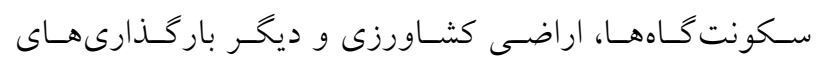
اقتصادى با توجه به نوع و نحوه كاربرى مىتواند تعادل سيستم رودخانه و محدوده رسوبى را در راستاى بِيدارى و نايايسدارى متأثر سازد. تغيير كاربرى اراضى، بهرهبردارى نامناسب و تجاوز به حريم و بستر شـبكه جريـانهـاى اصـلى و فرعى نـه تنهـا آسيبِيذيرى محيط را تشديد كرده بلكه موجب نايايدارى منابع مانند كاهش دبى بايه، افزايش سيلابها و تشديد فرسـايش را بهدنبال خواهد داشت. بدينمنظور شبيهسازى رياضسى رفتـار و الكوى جريان، تغييرات بستر و كنارهها امرى كاملاً ضـرورى و

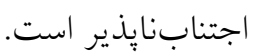

اثر تغييرات سطح اساس آببهاى آزاد و فعاليتهاى انسانى توجه داشتهاند. اما در اين بـزخوهش، تغييـر مورفوديناميـك رودخانـه در ارتباط با تغييـر در شـرايط جريـان در محسيطهـاى كـــــرزى و يرانرزى و نقش آن در تغيير ساختار فضـايى و ايجـاد مخــاطرات طبيعى بررسى مىشود. قابل ذكر است كـه شـبيهسـازى و تحليـل يارامترهاى هيدروليك جريان سيلابى و به تبـع آن بررسـى رونـــ تغييرات مورفولوزى در رودخانه مخروطافكنهاى و منطقـه مـورد مطالعه توسط مدلى دوبعدى جزء تكنيكهاى جديد است.

موقعيت منطقه مورد مطالعه محدوده مورد بررسى در اين يزوهش، بازهاى از رودخانه ديمه

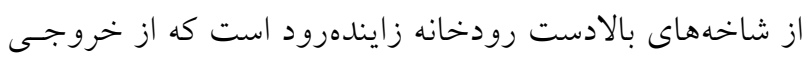
كانالهاى انتقال آب ا، r و r كوهرنگ در شهر آورگان شروع شده و تا محل اتصال رودخانه بِاسجان در بالادست درياجهه و سد زايندهرود قرار دارد. رودخانه ديمه از سرشاخههاى اصـلى سيلابى رودخانه زايندهرود و برآب بالادست سد زاينـدهرود در استان جهارمحال و بختيارى است. سيلابهاى ثبت شده از اين رودخانه ارقام سيلابى آن را تا سهم مترمكعسب در ثانيسه (سـال 


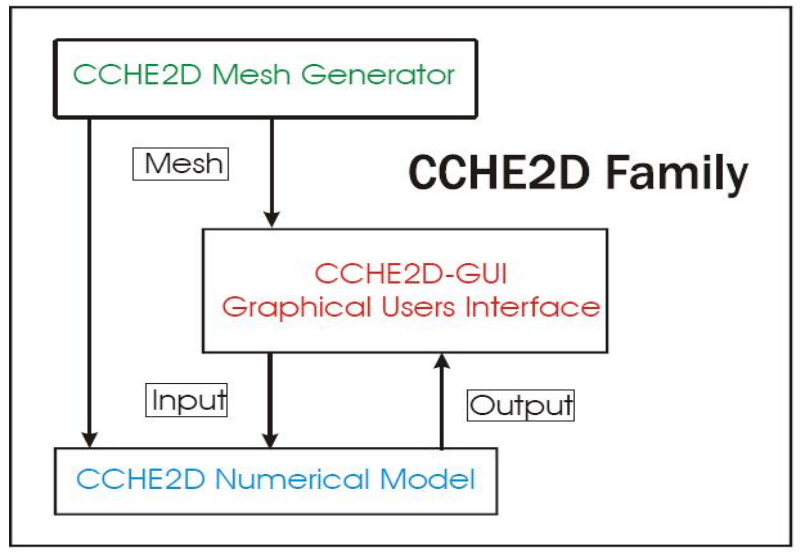

شكل r. روند شبيهسازى مدل CCHE2D

داده شده است (ro). (r).

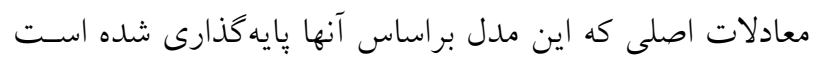

مدل CCHE2D

را مىتوان بهصورت زير ارائه كرد:

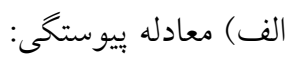

$\frac{\partial \mathrm{Z}}{\partial \mathrm{t}}+\frac{\partial(\mathrm{hu})}{\partial \mathrm{x}}+\frac{\partial(\mathrm{hv})}{\partial \mathrm{y}}=。$

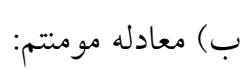

$\frac{\partial u}{\partial t}+u \frac{\partial u}{\partial x}+v \frac{\partial u}{\partial y}=-g \frac{\partial Z}{\partial x}+\frac{1}{h}\left(\frac{\partial\left(h \tau_{x x}\right)}{\partial x}+\frac{\partial\left(h \tau_{x y}\right)}{\partial y}\right)$

$-\frac{\tau_{\mathrm{bx}}}{\rho \mathrm{\rho h}}+\mathrm{f}_{\mathrm{cor}} \mathrm{V}$

$\frac{\partial v}{\partial x}+v \frac{\partial v}{\partial y}=-g \frac{\partial Z}{\partial y}+\frac{1}{h}\left(\frac{\partial\left(h \tau_{y x}\right)}{\partial x}+\frac{\partial\left(h \tau_{y y}\right)}{\partial y}\right)$

$$
-\frac{\tau_{\text {by }}}{\rho h}+f_{\text {cor }} u
$$

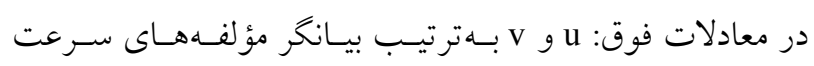

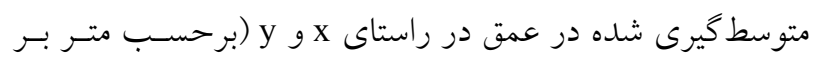

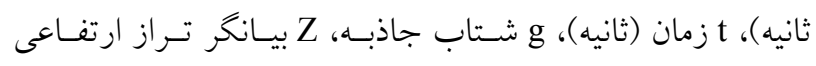

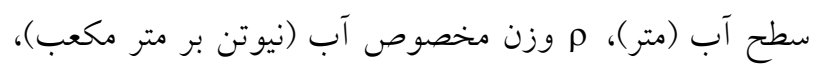

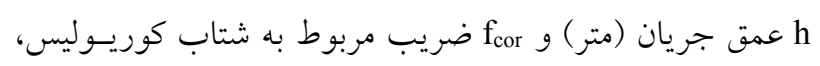

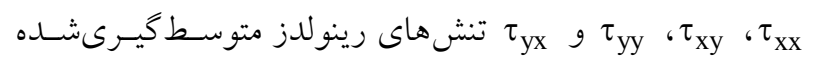

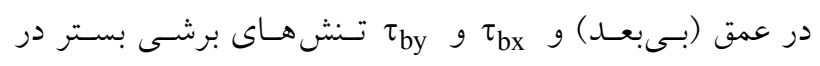
راستاى X و y (نيوتن بر متر مربع) هستند.

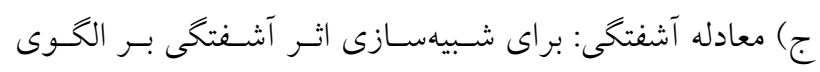

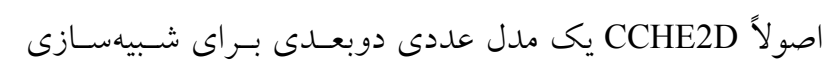

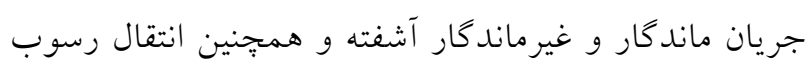

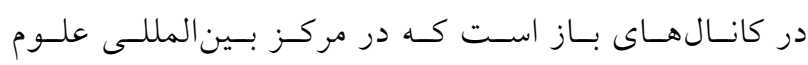

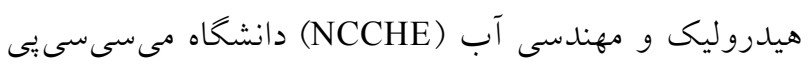

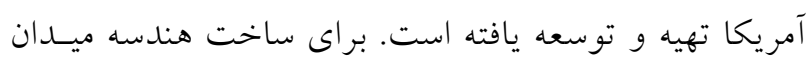

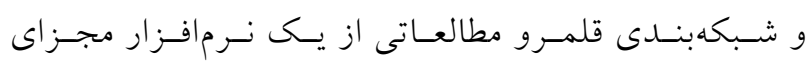

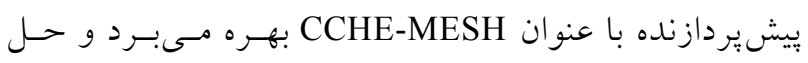
ميدان جريان و فرايند انتقال رسوب و همجنين مشاهده نتايج

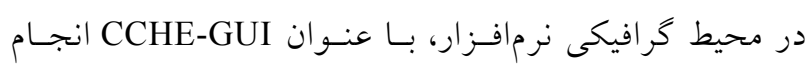

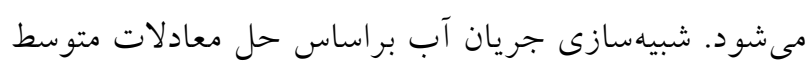
عمقى ناوير - استوكس است. تنش برشى متلاطم با استفاده

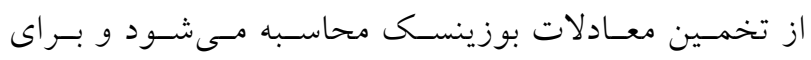

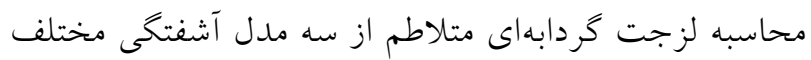

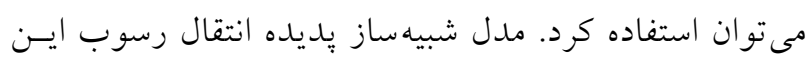

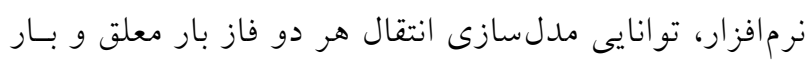

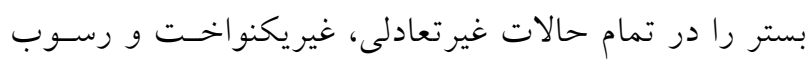

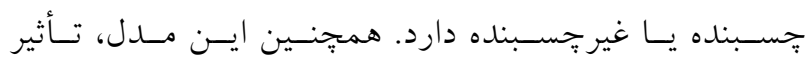

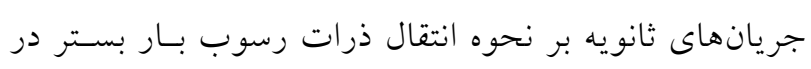

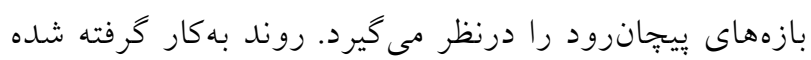
در مدل CCHE2D بهطور نمادين در شكل شـماره ب نشـان 


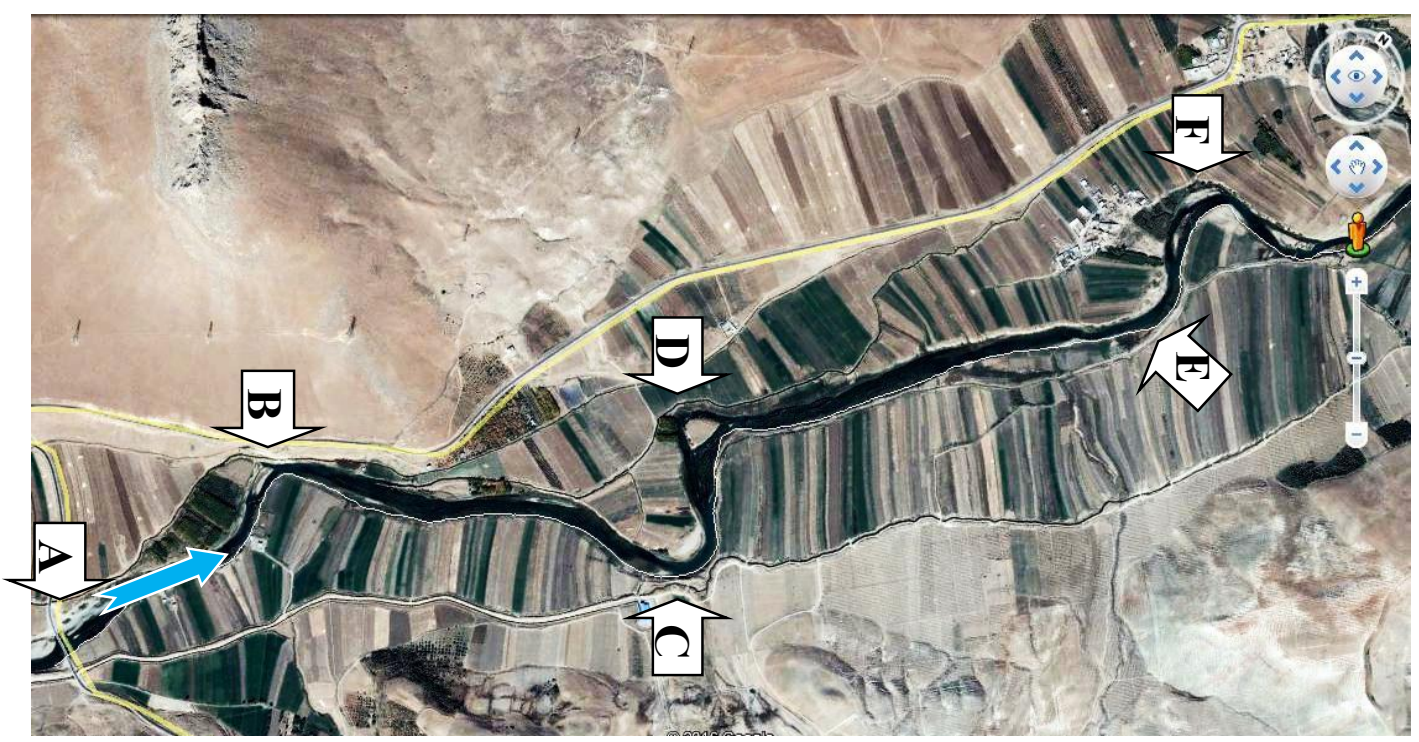

شكل r. نمايى از مقاطع اندازهيرى پارامترهاى جريان بازه مورد مطالعه رودخانه ديمه

جدول ا. مشخصات دستخاه سرعتسنج صوتى Easy QTM

\begin{tabular}{|c|c|c|c|}
\hline دامنه گام زمانى اندازهگيرى & دامنه اندازهيرى عمق جريان & حداكثر سرعت قابل اندازهيرى & كاربرد \\
\hline $1-1 Y \circ S$ & $\circ / 10-10 \mathrm{~m}$ & $1 \circ \mathrm{m} / \mathrm{s}$ & سنجش سرعت و عمق جريان \\
\hline
\end{tabular}

دستخاه سرعتسنج صوتى Easy QTM و شـاخص انـدازه خيـرى استفاده شد. در جدول ( (1) مشخصات سرعتسنج مذكور آورده شده است. براى انــازه گيـرى دقيـق سـرعت جريـان، دســاه

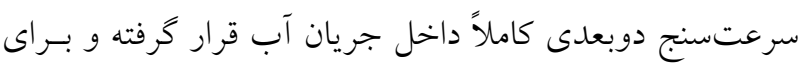
اين هدف، يك ثبات (مشابه يل تلفريـك) طراحسى و سـاخته و سبس دسـتحاه روى آن نصـب شـــ تـا در هـر مرحلـه قرائـت،

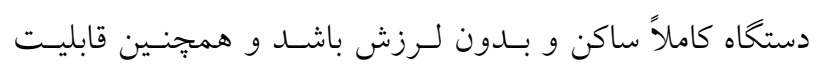
جابهجايى در عرض، براى برداشت دادههـاى جريـان از سـاحل سمت جِب تا راست و هم قابليت جابهجايى در عمق رودخانسه را براى برداشت جريان از سطح آب تا كـف بسـتر بـه فواصـل

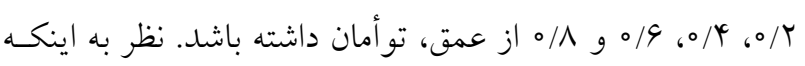
در جريانهاى سيلابى مقدار سـرعت در نقـاط مختلـف عـرض رودخانه و همجنين در اعماق آب متغير و همراه با تلاطم است، سرعت متوسط در طول هر مقطع (با توجه به عرض هر مقطع)

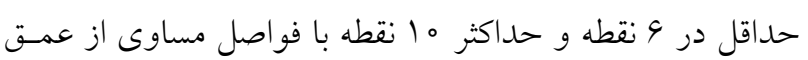

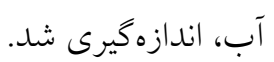

جريان و بستن سيستم معادلات حاكم، مدل CCHE2D، از سـه

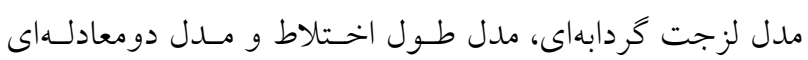
K- بهره مىبرد.

اندازه گيرى دادههاى ميدانى و آزمايشـحاهى موردنيـاز مـدل CCHE2D نقشهبردارى و اندازهيرى بֶارامترهاى جريان بازه مورد مطالعه در كام نخست اين بزّوهش، بـه نقشـهـــردارى بـازه انتخـابى از

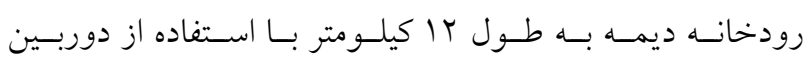

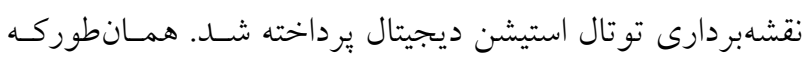
در شكل (r) مشهود اسـت، در شـش مقطع عرضسى از مقـاطع نقشهبردارى شده به اندازه گيرى پيار امترهاى جريان برداخته شـد

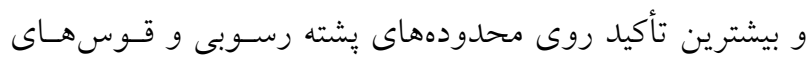

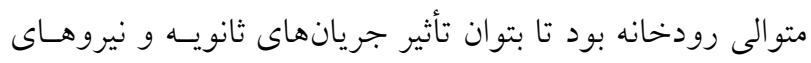

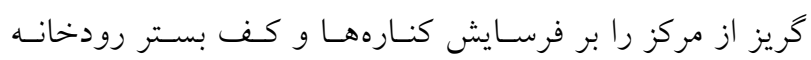

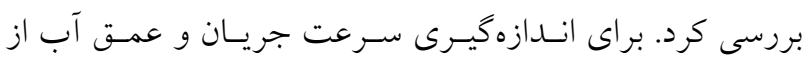


نشريه علوم آب و خاك (علوم و فنون كشاورزى و منابع طبيعى) / سال بيست و سه / ويزُهنامه سيل و فرسايش خاك / زمستان \هـا

جدولr ـ مقادير بارامترهاى سرعت، عمق و دبى جريان اندازه گيرى شده در مقاطع مختلف بازه مورد مطالعه

\begin{tabular}{|c|c|c|c|c|c|c|c|}
\hline دبى جريان & عمق جريان & $\begin{array}{c}\text { سرعت متوسط } \\
\text { (m/s) }\end{array}$ & در عمق مرعت & در عمق 2 سوعت & در عمق عرعته & در عمق & مقاطع اندازهيرى \\
\hline $1 N / T$ & $1 / 0 Y$ & $1 / 11$ & $\circ / \wedge \Delta$ & $\circ / 9$ & $I / T V$ & $1 / 9$ & مقطع (B) \\
\hline $1 N / T$ & $1 / 1 Y^{c}$ & $1 / T \Delta$ &.$/ 9 r$ & $1 / 10$ & $1 / \pi \Lambda$ & $1 / 94$ & مقطع (C) \\
\hline $1 N / r$ & $1 / T V$ & $1 / T \Lambda$ & $\circ / \Lambda$ & $|/ T|$ & $1 / 4$ & $1 / V$ & مقطع (D) \\
\hline $1 N / T$ & $1 / \pi \Delta$ & $1 / 44$ & 。/Ar & $1 / 1 \Lambda$ & $1 / T 4$ & $1 / 9 \mathrm{~V}$ & مقطع (E) \\
\hline $1 N / T$ & $1 / 0 r$ & $1 / 19$ & $\circ / V \wedge$ & $1 / 09$ & $1 / 79$ & $1 / 00$ & مقطع (A) ورودى \\
\hline $1 N / T$ & $1 / 4 \wedge$ & $1 / 4$ & $1 / \circ 0$ & $1 / T r$ & $1 / 00$ & l/Ar & مقطع (F) خروجى \\
\hline
\end{tabular}

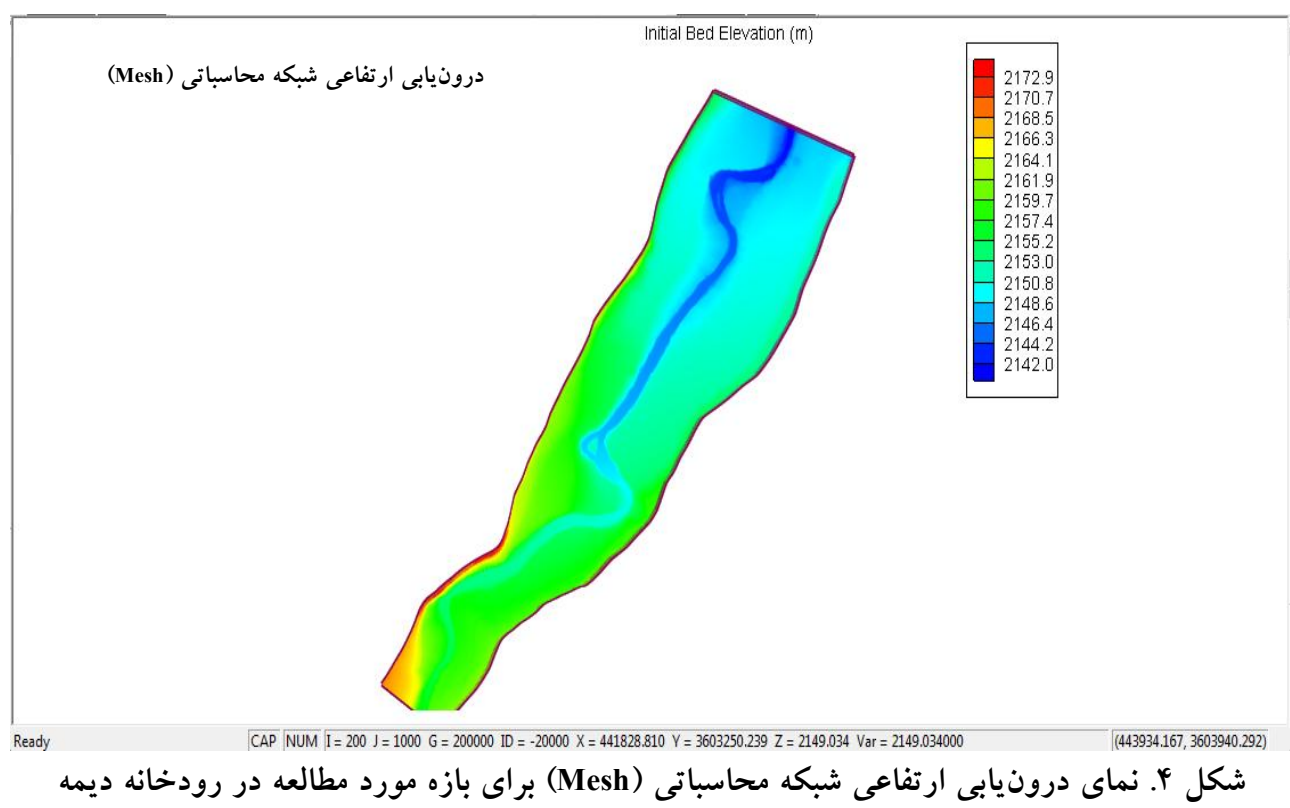

شايان ذكر است با توجه به اينكه مسـل دوبعـدى اسـت و از رودخانه ديمه اندازهيرى شده است. ميانخين عمق بهره مىبرد، بهمنظور واسنجى و صحت سـنجى

در بخش اندازه كيرى نيز با استفاده از روش يــنجنقطهاى، از توليد شبكه محاسباتى در مدل عددى CCHE2D نقاط مختلف در عرض هر مقطع در راستاى عمقى ميـانخين همانطور كه عنوان شد در مدل CCHE2D براى ساخت هندسه

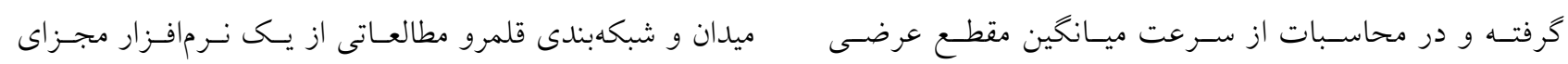
بيش بيردازنده با عنوان CCHE-MESH، استفاده مىشود. ي-س از استفاده شد. همانطور كه در جدول (Y)، مشاهده مىشود براى جريـان ورود دادههاى هندسى حاصل از نقشهبردارى به محيط نرمافـزار بازه مورد مطالعه، يارامترهايى از قبيـل سـرعت، دبسى و عمـق و تعيين مرزها، محدوده موردنظر با استفاده از روشهاى جبرى جريان در مقاطع مذكور و ابتـدا و انتهـاى بــازه مـورد مطالعـه و محاسـباتى شـبكهبنـدى شـــ. ابعـاد بهينـه شـبكه محاسـباتى 
جدول r. مقايسه پارامتر سرعت جريان (m/s) در حالت تغيير ضريب زبرى و ابعاد شبكه محاسباتى

\begin{tabular}{|c|c|c|c|c|c|}
\hline \multirow{3}{*}{ اندازه مقيرى شده } & \multirow{3}{*}{$\begin{array}{c}\text { يارامتر سرعت جريان } \\
\text { (m/s) }\end{array}$} & \multicolumn{4}{|c|}{ يارامتر سرعت جريان (V) يِيشبينى شده توسط مدل (m/s) } \\
\hline & & \multicolumn{2}{|c|}{ ابعاد IV०×NY } & \multicolumn{2}{|c|}{ 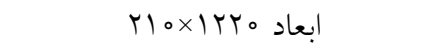 } \\
\hline & & $\begin{array}{c}\text { زبرى } \\
\left(\circ / \mu^{\prime}-0 / 0 \mu\right)\end{array}$ & $\begin{array}{c}\text { زبرى } \\
\left(\circ / \circ{ }^{\circ} / 0 \Delta r\right)\end{array}$ & $\begin{array}{c}\text { زبرى } \\
(\circ / 0 \mu-0 / 0 \mu)\end{array}$ & $\begin{array}{c}\text { زبرى } \\
(0 / 0 r-\circ / 0 \Delta r)\end{array}$ \\
\hline مقطع B مقع & $1 / 1 \wedge$ & $1 / N r$ & $1 / 99$ & $1 / 00$ & $1 / T V$ \\
\hline مقطع C & $1 / T \Delta$ & l/Ar & $1 / V 9$ & $1 / 9$ & $1 / 41$ \\
\hline Dقطع Dق D D & $1 / \Gamma \wedge$ & $1 / \wedge 1$ & $1 / 94$ & $1 / 91$ & $1 / 0 T$ \\
\hline مقطع E & $1 / 49$ & $1 / \Lambda \Lambda$ & $1 / V$ & $1 / 9$ & $1 / 4 \wedge$ \\
\hline مقطع A (ورودى) & $1 / 19$ & $1 / 9 \mu$ & $1 / 09$ & $1 / 4 \pi$ & $1 / \mu x$ \\
\hline مقطع F (خروجى) & $1 / 4$ & $1 / 9$ & I/AV & $1 / N r$ & $1 / 94$ \\
\hline
\end{tabular}

بر نتايج ملدل، مرحلـه بعـدى واسـنجى مـدل عـددى CCHE2D

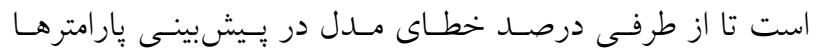

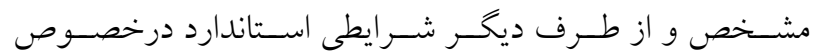

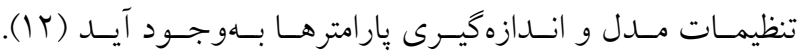

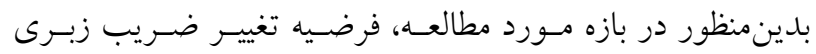
(حساستـرين جــارامتر) بــر الخـوى جريــان بـا اسـتفاده از مقــدار تخمينى (مشاهدات صحرايى) در دامنه بره/ تا سوه/ مو تغييـر

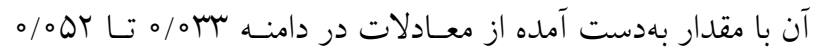
مقايسه شد؛ همحِنين براى داشتن بهترين شر ايط پِيـه در سـاخت

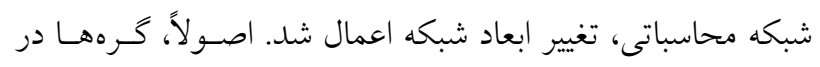
شبكه از تلاقىى بردارهـاى طـولى (II) و عرضسى (J) بـا يكـديخر بهوجود مى آيند و هر كره معرف برايند ويزگى هاى جهـار سـلول

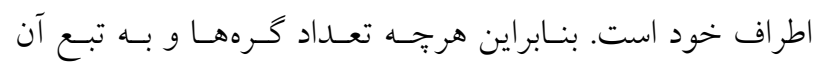
سلولهاى ايجاد شــه در مقطع عرضسى رودخانـهـ بيشـتر باشـد، شبكه توليد شده و الكوى جريان شبيهازى شده، دقـت بـالاترى

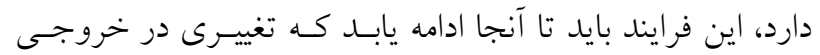
مدل مشاهده نشود (ب). براى ريزتـر كـردن شـبكه توليــد شـده،

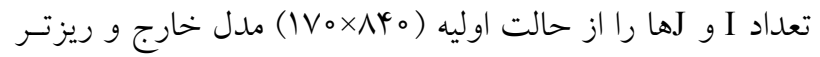
كرد و اين فرايند تا آنجايى ادامه داده شد كه تغييرى در خروجسى

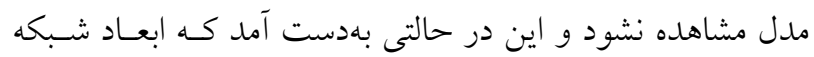

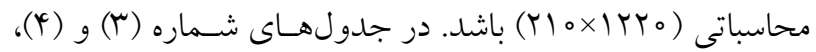

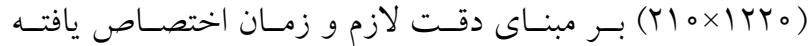
بهمنظور انجام محاسبات، انتخاب شده است. همانطـور كـه در شكل (Y) نشان داده شده است، با توجه به شكل :ـالان، حالـت تك بلوكى براى نرمافزار توليد شبكه انتخاب شد (مَ). شبيهسازى الخوى جريان CCHE-GUI مراحل شبيهسازى الكوى جريان توسط نــرمافـزار به شرح زير است (بّ): ورود و فراخوانى فايل Geo، تنظيم شرايط اوليه جريان (تـراز آب بالادست و ياييندست و ضريب زبرى) بر اساس اندازهيرىهاى انجام شده در جدول (Y)، تنظيم پِار امترهاى جريان (كَام زمـانى،

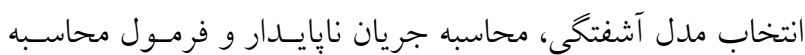
زبرى)، تنظيم شرايط مـرزى ورودى و خروجـى رودخانـه (دبسى جريان ماندكار، تراز سطح آب) و اجراى شبيهسازى. ضـمناً بـراى كاليبراسـيون و صسحتسـنجى مــل عـددى CCHE از تغييـرات دادههاى ضريب زبـرى و ابعـاد شـبكه محاسـباتى بهـره بــرديم و سيّ نتايج حاصل از شبيهسازى مدل را بـا دادههـاى مشـاهداتى مقايسه و به حالت إيتيمم دست بيدا كرديم.

\section{واسنجى مدل عددى CCHE2D}

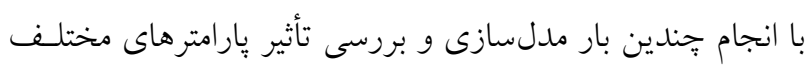


نشريه علوم آب و خاك (علوم و فنون كشاورزى و منابع طبيعى) / سال بيست و سه / ويزُهنامه سيل و فرسايش خاك / زمستان \هـ|

جدول fا. مقايسه يٍارامتر عمق جريان (m) در حالت تغيير ضريب زبرى و ابعاد شبكه محاسباتى

\begin{tabular}{|c|c|c|c|c|c|}
\hline \multirow{3}{*}{ اندازه ميرى شده } & \multirow{3}{*}{ 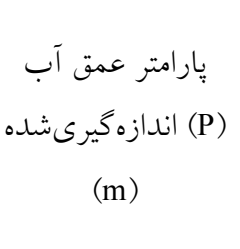 } & \multicolumn{4}{|c|}{ يارامتر عمق آب (P) ييشبينىشده توسط مدل (m) } \\
\hline & & \multicolumn{2}{|c|}{ lVoxNY0 } & \multicolumn{2}{|c|}{ ابعاد } \\
\hline & & $\begin{array}{c}\text { زبرى } \\
(0 / 0 \mu-0 / \circ \mu)\end{array}$ & $\begin{array}{c}\text { زبرى } \\
\left(\circ / \circ r_{-} / 0 \Delta r\right)\end{array}$ & $\begin{array}{c}\text { زبرى } \\
(0 / 0 \mu-0 / 0 \mu)\end{array}$ & $\begin{array}{c}\text { زبرى } \\
\left(\circ / \circ r_{-\circ \Delta r)}\right)\end{array}$ \\
\hline مقطع B مق & $1 / 0 Y$ & I/N & $1 / Q Y$ & $1 / 90$ & $1 / r \mu$ \\
\hline مقطع C & $1 / 14$ & $\Gamma / \Lambda \Lambda$ & $1 / 90$ & $1 / 94$ & $1 / \pi 1$ \\
\hline مقطع Dق D م & $1 / T \Lambda$ & l/Ar & $1 / N Q$ & $1 / 4 V$ & 1/ת \\
\hline مقطع E مقع & $1 / \pi \Delta$ & $1 / 94$ & $1 / 0 r$ & $1 / 09$ & $1 / 4 V$ \\
\hline مقطع A (ورودى) & $1 / 0 r$ & I/AV & $1 / V 9$ & $1 / \mathrm{V}$ & $1 / 19$ \\
\hline مقطع F (خروجى) & $1 / 4 \wedge$ & $1 / 94$ & $1 / 01$ & $1 / Q Y$ & $1 / 40$ \\
\hline
\end{tabular}

جدول هـ نتايج مقايسه سرعت جريان، عمق آب و شيب انرزى مشاهداتى و براوردى با استفاده از مدل ع-k و بر اساس دو معيار آمارى

\begin{tabular}{|c|c|c|c|}
\hline ن نوع روش & يارامتر سرعت جريان آب & يارامتر عمق آب & يارامتر شيب انرزى \\
\hline RMSE & $\circ / \circ V Q$ & $0 / 119$ & $\circ / \circ \circ \circ \wedge$ \\
\hline MAPE & $\circ / 0 T V$ & $0 / 094$ & $0 / 0 y+$ \\
\hline
\end{tabular}

مدل در شبيه سازى سرعت، عمق و شيب انرزى آشكار شـود.

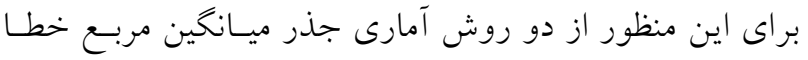
و ميـانخين درصسد خطـاى مطلـق (RMSE)

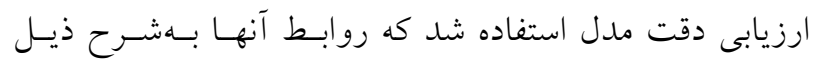

$$
\text { R.M.S.E }=\sqrt{\frac{1}{n} \sum_{i=1}^{n}\left(Q_{o}-Q_{e}\right)^{r} \mid}
$$

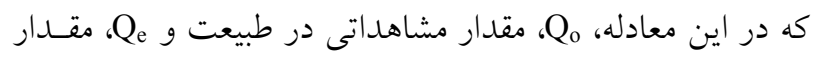

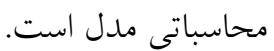

$$
\text { M.A.P.E }=\frac{1}{n} \sum_{i=1}^{n}\left|\frac{y_{t}-\hat{y}}{y_{t}}\right| \times 100
$$

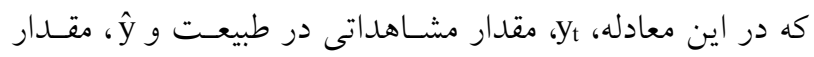

$$
\text { محاسباتى مدل است. }
$$

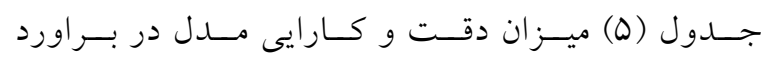

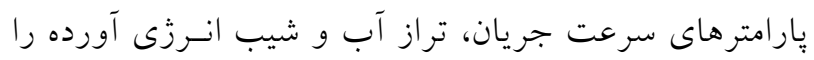
نشان مىدهد.
مقادير اندازهكيرى شده و شبيهسازى شده بـراى سـرعت جريـان

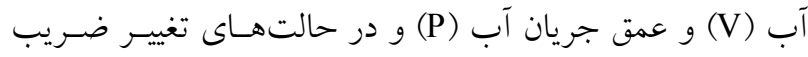
زبــرى و تغييــر ابعـاد شـبكه محاسـباتى مقايسـهـ شـــه اسـتـ.

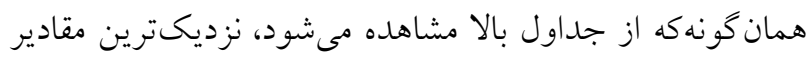

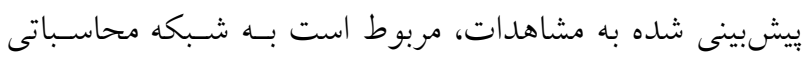

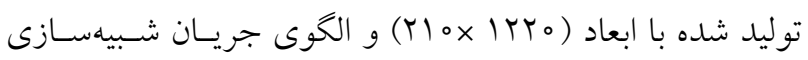

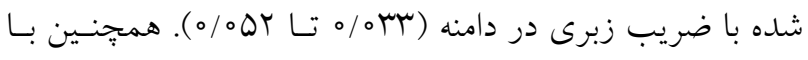

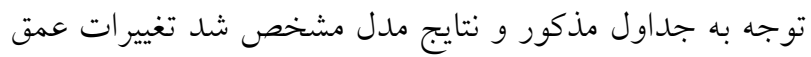

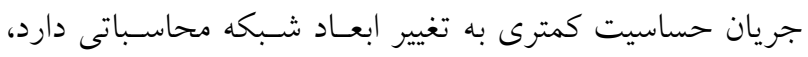

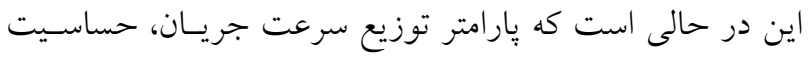
زيادى (بهويزه در محدودهه مقعر قوس رودخانه) به تغييـر ابعـاد

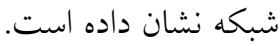

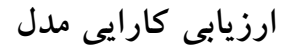

در ادامه، نتايج بهدست آمده از مدل با دادههـاى انــازهكيـرى مدرى

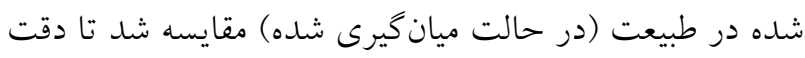



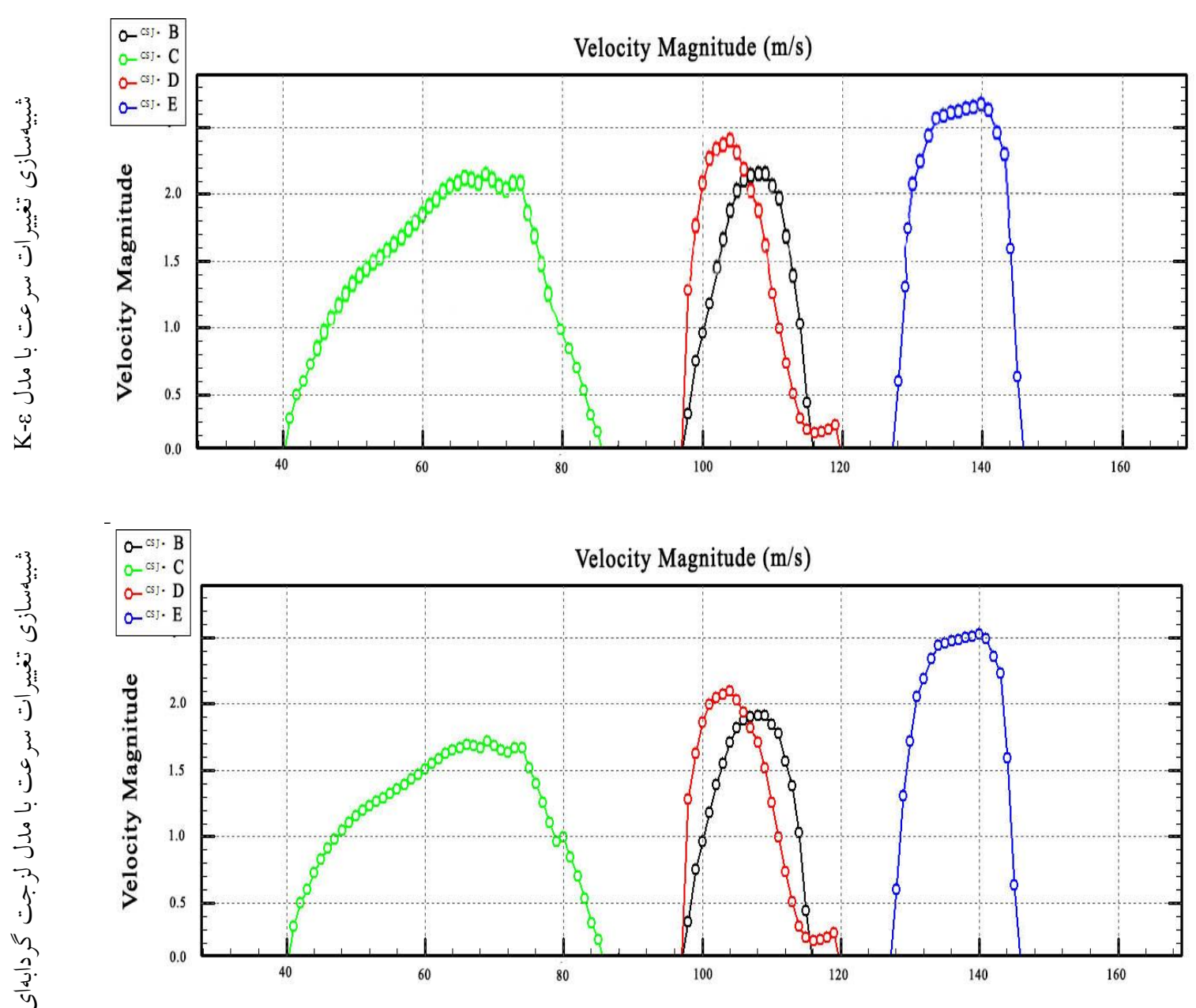

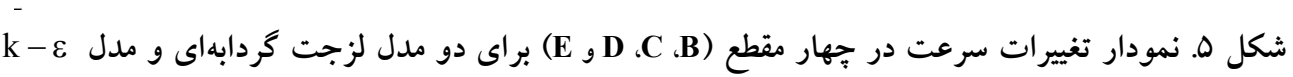

همان كونه كه از شكل و جدول بالا مشاهده مىشـود، مقــادير

شبيهسازى شده با استفاده از مدل آشفتگكى ع-k از دقت بالاترى

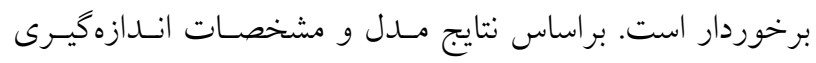

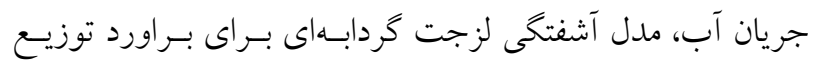

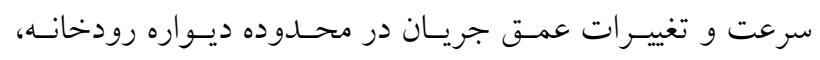
بهويزه قسمت مقعر قوس رودخانه داراى دقت كمترى است، امـا

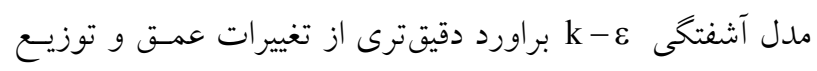
سرعت جريان براى محدودههاى مزبور دارد.

$$
\text { بررسى پارامترهاى سرعت جريان آب و تنش برشى }
$$

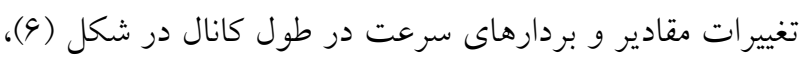
نشان مىدهد كه در بـازه مستقيم قبـل از قـوس اول، مـاكزيمم
يافته ها و بحث بررسى مدلهاى آشفتگى جريان

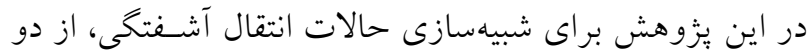
مدل لزجت كردابهاى و مدل ع-k استفاده شد. همانطور كه

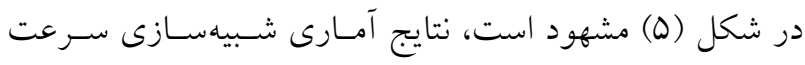

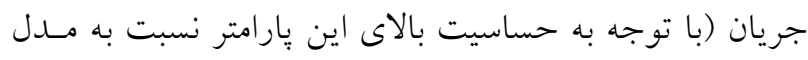

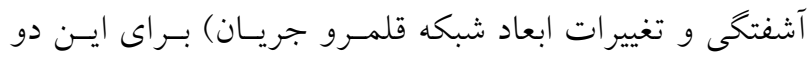

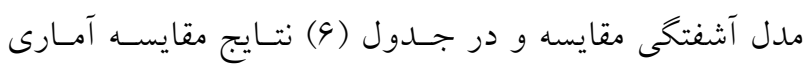

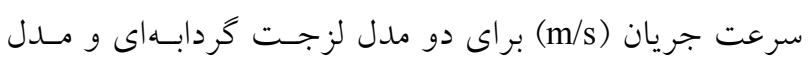

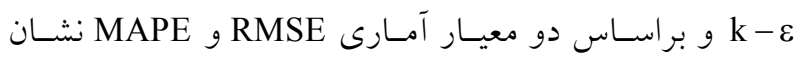

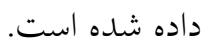


جدول و. نتايج مقايسه آمارى سرعت جريان (m/s) براى دو مدل لزجت گردابهاى و مدل ع-k و بر اساس دو معيار آمارى MAPE و RMSE

\begin{tabular}{|c|c|c|}
\hline نوع روش & مدل لزجت كردابهاى & مدل ع- \\
\hline RMSE & O/OTG & $0 / 011$ \\
\hline MAPE & $0 / 01 \mathrm{~V}$ & $0 / 014$ \\
\hline
\end{tabular}

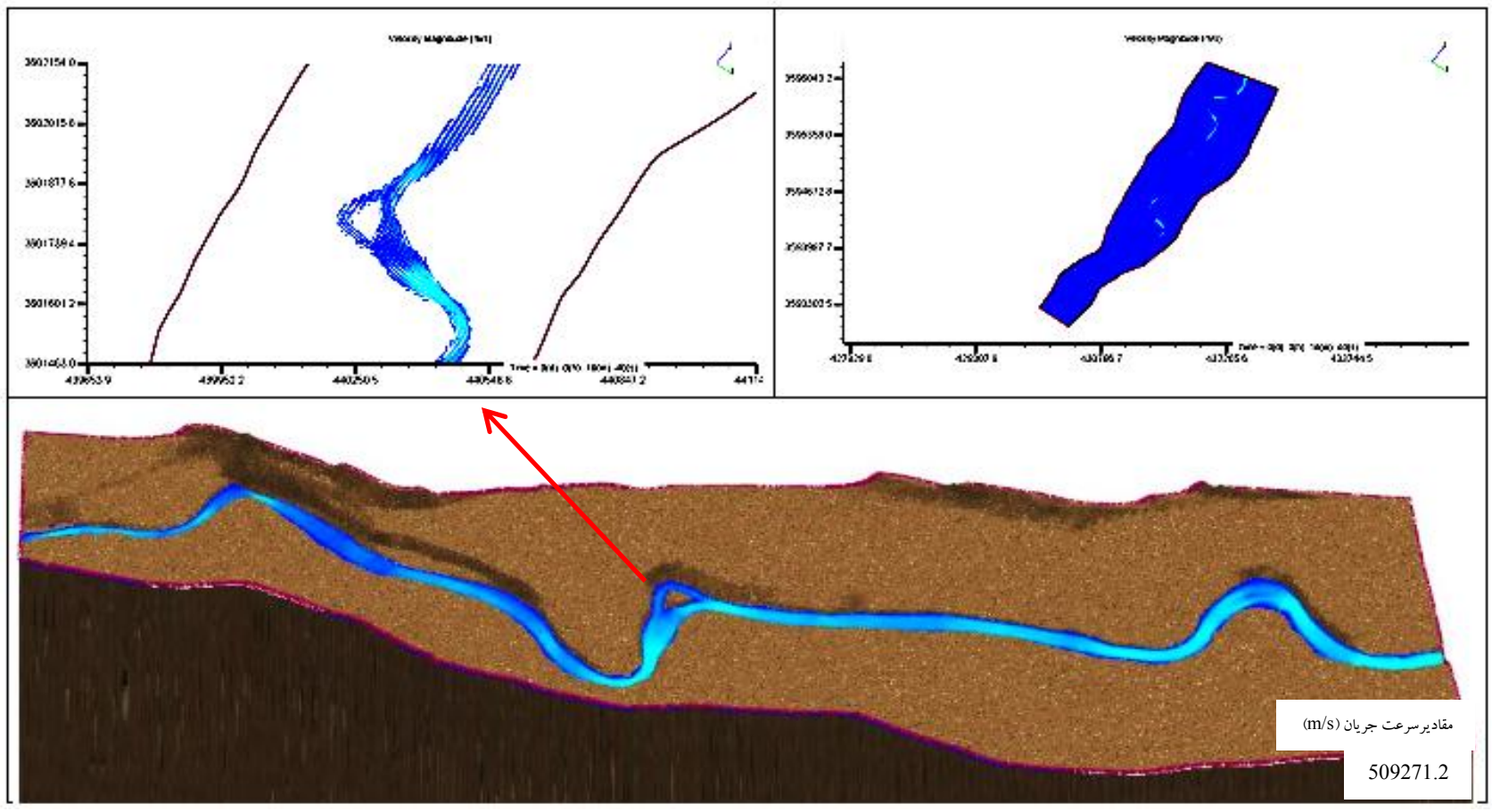

شكل 9. توزيع متغير سرعت در بازه مورد مطالعه روخانه ديمه

همانند توزيع سرعت، ماكزيمم مقدار تنش برشسى آب در بسـتر

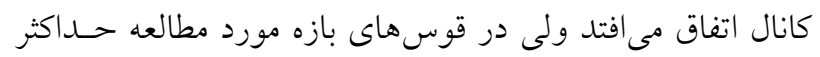

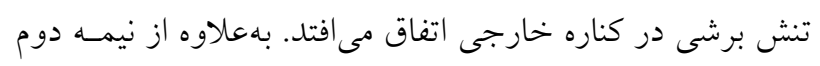

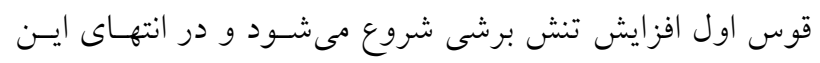

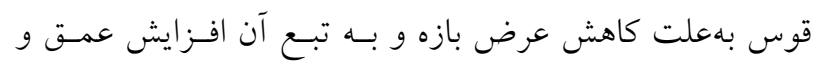

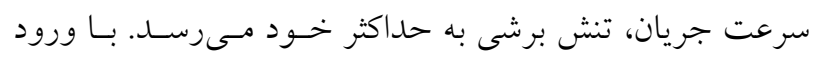

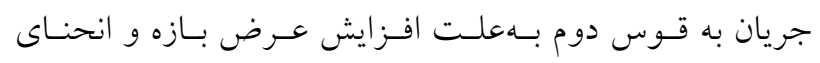

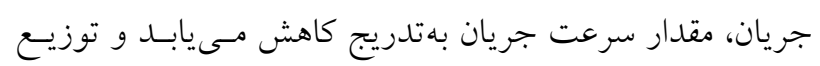

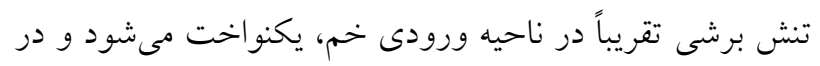

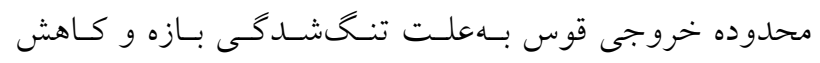

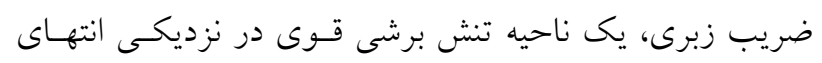

مقدار سرعت آب در وسط كانال اتفاق مىافتد. افزايش ضريب زبرى بازه مستقيم بالادست قوس اول، سبب

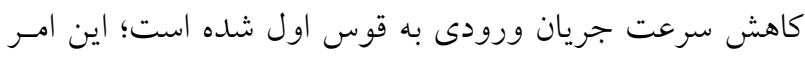
و انحناى بالاى قوس باعث مىشود كه تغييراتى مانــــ جريـان

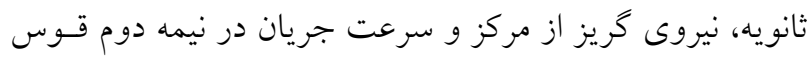

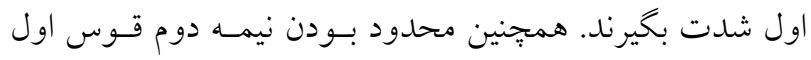

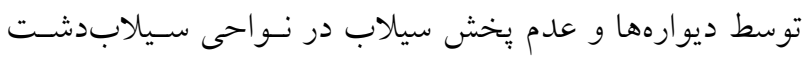

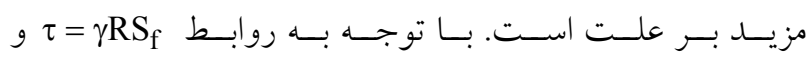

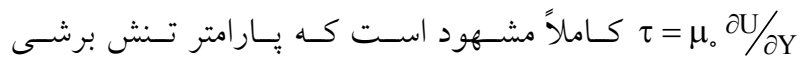
رابطهاى مستـقيم بـا كر اديـان سـرعت دارد؛ همـانطـور كـه در

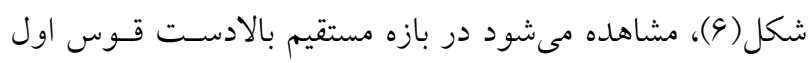




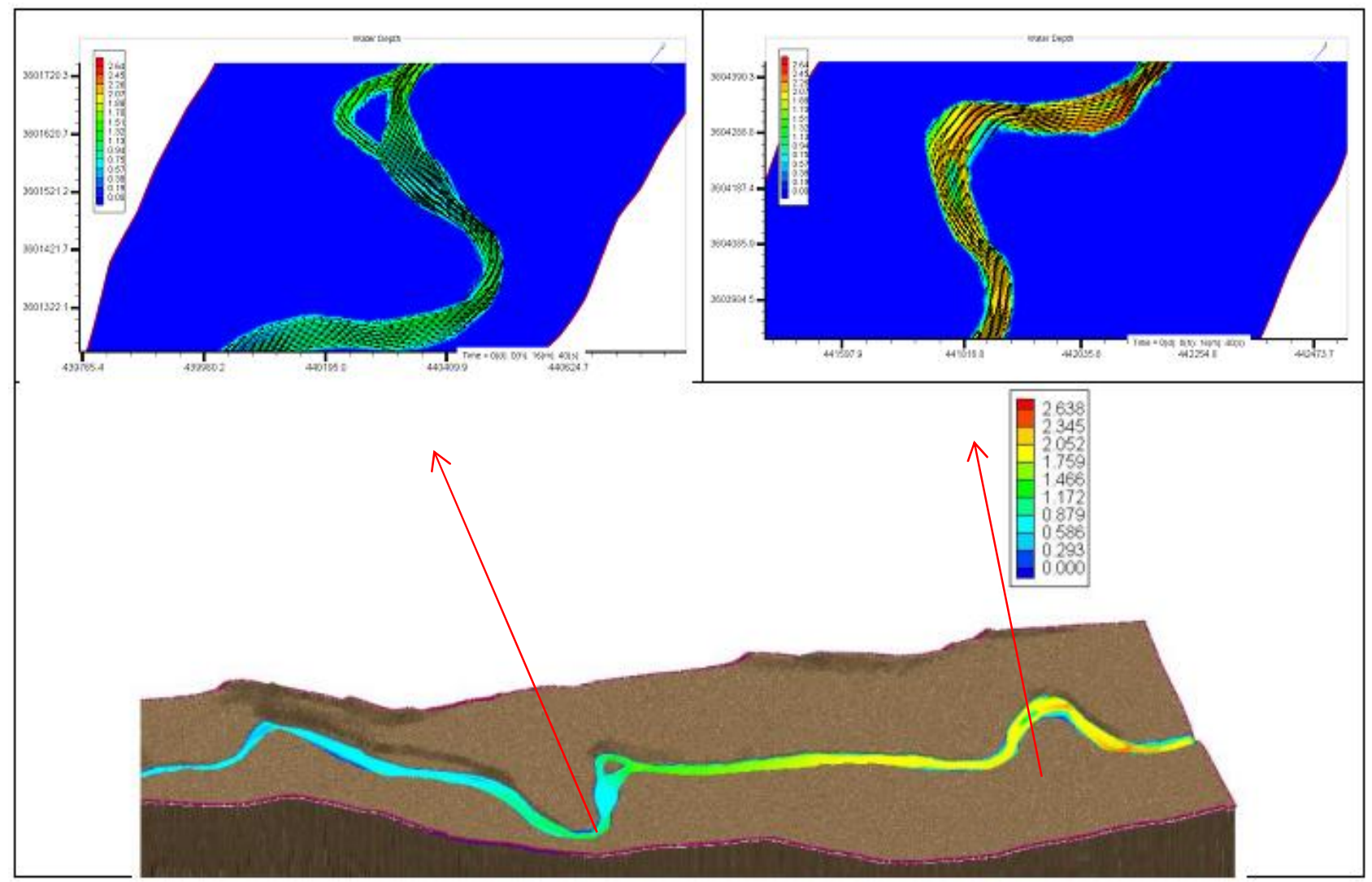

شكل V. تصوير توزيع متغير عمق جريان

اول داراى ضريب زبرى بالاترى نسبت به محدوده قوس است

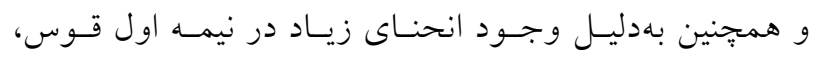

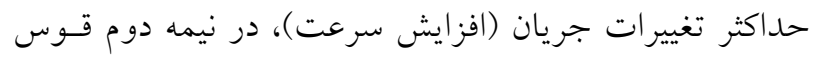

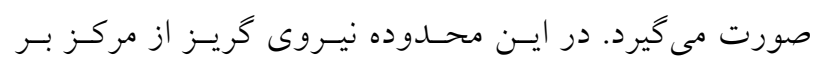

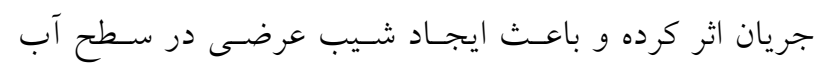

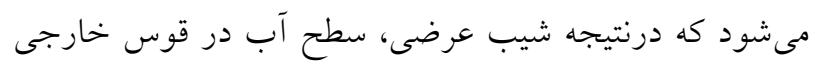

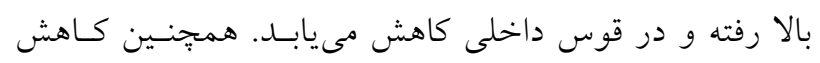

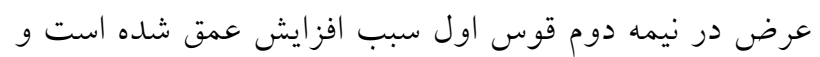

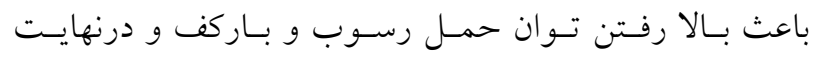

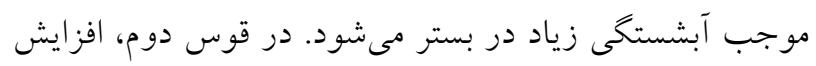

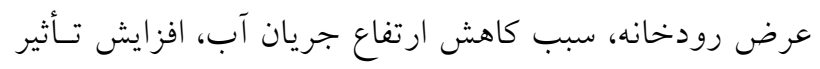

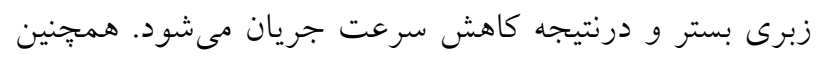

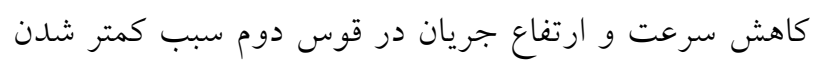

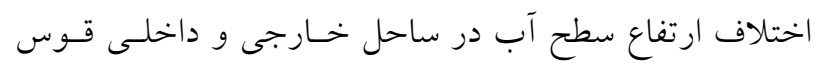

قوس اتفاق مىافتد. در قوس سوم با ورود جريـان بـهـ قـوس و

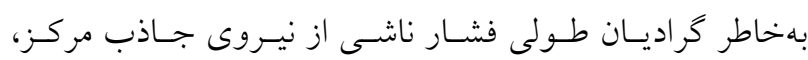

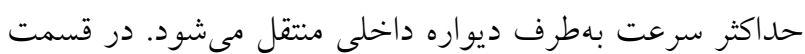

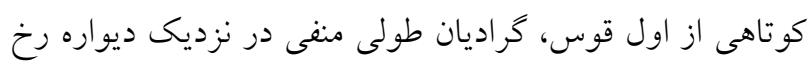

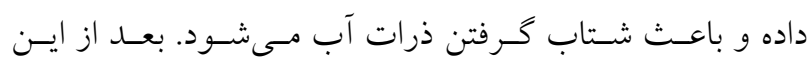

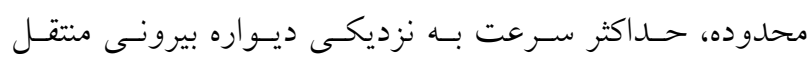

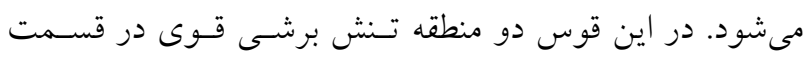
ابتداى قوس داخلى و در جداره بيرونى كانال كـه مـاكزيمم مقــدار

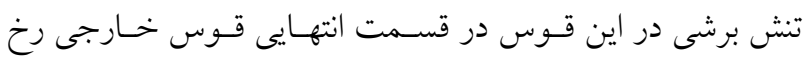

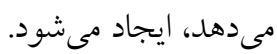

$$
\text { جارامتر عمق آب }
$$

همانطور كـه در شـكل (V) نشـان داده شـــه اسـت بـا ورود

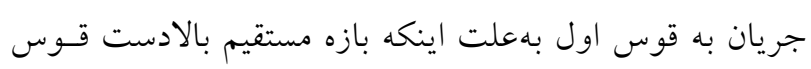




$$
\text { وجود نخصال (كستستى) معادلات حاكم بـر جريـان درنتيجـه نهـايى }
$$

تغييرات عمق جريان، حساسيت كمترى به تغيير ابعاد شـبكه

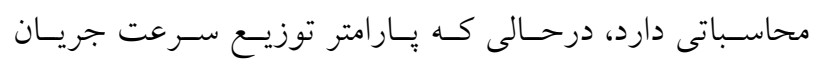

حساسيت زيادى (بهخصوص در محدوده مقعر قوس رودخانه)

$$
\text { به تغيير ابعاد شبكه دارد. }
$$

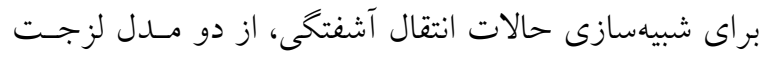

كردابهاى و مدل ع- k استفاده و معلوم شد كه بهطور متوسط سيط

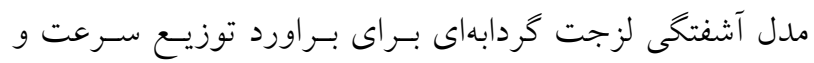

تغييرات عمق جريان در كل قلمرو جريان مناسب اسـت امـا در

محدوده ديواره رودخانه بهويزه قسـمت مقعـر قـوس رودخانسه

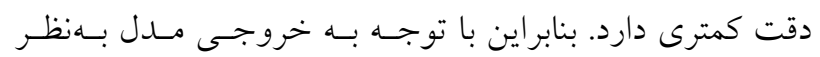

مىرسد براى براورد تغييرات عمق و توزيع سـرعت جريـان در

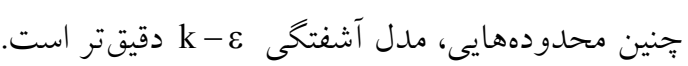

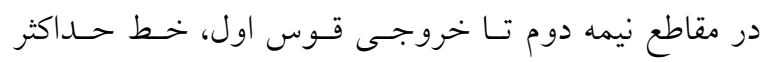

سرعت در جداره خارجى كانال قرار گرفته و تـا انتهـاى كانسال

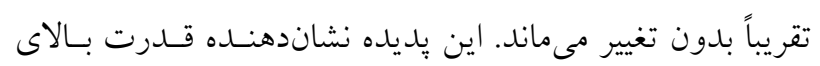

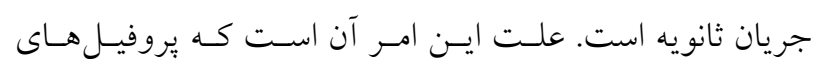
سرعت در مقاطع عرضى واقـع در نيمـه دوم قـوس بـه حالـت توسعه يافته رسيده و مقادير سرعت بين دو مقطع تغيير تجنـدانى ندارد؛ همجينين شيب نسبتاً بالاى بستر و محدود بودن اين ناحيه از رودخانه توسط ديوارهها و عـدم يخخـش سـيلاب در نـواحى

$$
\text { سيلاب دشت مزيد بر علت است. }
$$

دوم نسبت به قوس اول مىشود. بهطور كلى از قـوس دوم بـــ سمت باييندست ضريب زبرى بازه مورد مطالعه كاهش يافتسه. و سرعت جريـان افـزايش مسى يابـــ. در قـوس سـوم، كـاهش ضريب زبرى و افزايش انحناى قوس باعـث مسىشـود كـه در

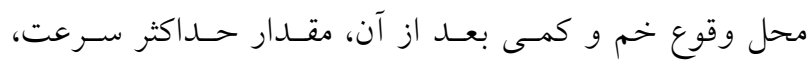
متمايل به ديواره خارجى (مقعر) ايجاد شود كه سبب افـزايش ارتفاع در قوس مقعر مى شود.

$$
\text { تتيجه كيرى }
$$

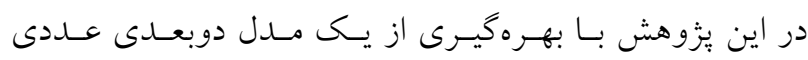

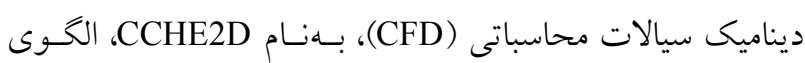
جريان آب در يك بازه بيجزانرود طبيعى شبيهسازى شد و نتايج

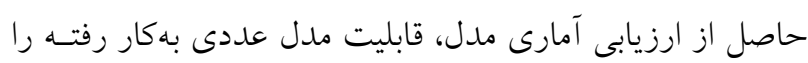
در بيشبينى پيار امترهاى جريان آب تأييد كرد.

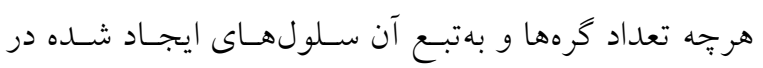

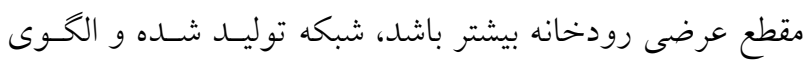
جريان شبيهسازى شده، دقت بالاترى دارد زيرا با افزايش تعـداد كرهها، تعداد بيشترى از دادههـاى جريـان، برداشـت شــده و در نتيجه يُات و نمودارهاى استخراج شده، قدرت تفكيك بالاترى دارند. اهميت اين موضسوع از مقايسـه نتـايج بــراوردى مــل و و مشاهداتى در مقاطع اندازهيرى شده بيشتر مشخص شد. شايان

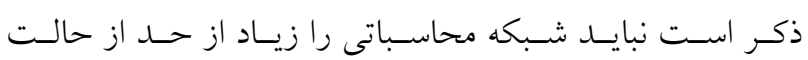

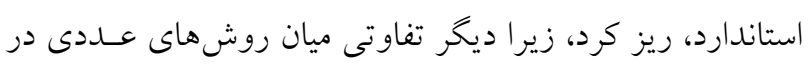

\section{منابع مورد استفاده}

1. Abbasi Chenari, Q. 2011. Investigation of the effect of geometry and distance of a non-submerged gullet on flow pattern in river arch using numerical models, In: Proceeding of the Fifth National Conference on Watershed Management and Water Resources Management, Kerman. (In Farsi).

2. Arizona Department of Transportation. 1988. Analysis of Flow an Alluvial Fans, Report number : FHWA-AZ88802.P:53.

3. Azarang, F.; M. Shafaei Beheshtani, B. Dehanzadeh and B. Shahinejad. 2009. Application of CCHE model in hydraulic and sedimentary simulation of the river (case study: karun river, ahvaz-farsiat basin). In: Proceeding of the Eighth International Seminar, Tehran University Martyr Chamran Ahvaz. (In Farsi). 
4. Azizian, A., M. Gholizadeh and A. Amiri Tkeldani. 2009. Simulation of Cochlear migration process (meander rivers) using CCHE2D numerical model. In: Proceeding of the Eighth International Seminar on River Engineering, Shahid Chamran University of Ahvaz. (In Farsi).

5. Committee on Alluvial Fan Flooding, National Research Council. 1996. Alluvial Fan Flooding, 182pp.

6. Farhadi, A. 2005. Measuring and investigation of kykhanrood route and cutoff of kazemabad waterway, In: Proceeding of the Fifth Iranian Hydraulic Conference, Faculty of Engineering, Shahid Bahonar University of Kerman. (In Farsi).

7. Fathi, M. and A. Artistic. 2011. Modeling flow pattern with CCHE2D in a natural twist, MSc. Thesis, Shahrekord University. (In Farsi).

8. Federal Emergency Management Agency (FEMA). 2000. Guidelines for Determining Flood Hazard on Alluvial Fans, 23pp.

9. FEMA. 2000. Guidelines and specifications for flood hazard mapping parameters.

10. Ghavasieh, A. and A. Nowruz. 2008. Investigation of the effective conditions on riverbed multipruncation (case study: varamin rotary alloy). In: Proceeding of the $7^{\text {th }}$ Iranian Hydraulic Conference, Shahid Abbaspour University. (In Farsi).

11. Guide to the Application of Mathematical and Physical Models to Engineering and River Studies in the River. 2007. Journal No. 320-A, Vice President of Strategic Planning and Supervision.

12. Isfahani, K. M. and A. Diving. 2005. Flood zoning analysis in alloys, In: Proceeding of the $5^{\text {th }}$ Iranian Hydraulic Conference, Shahid Bahonar University of Kerman. (In Farsi).

13. Jia, Y. F. and S. Wang. 2001. CCHE2D :Two-dimensional Hydrodynamic and Sediment Transport Model for Unsteady Open Channel Flow Over Loose Bed. NCCHE Technical Report.NCCHE-TR-2001-01.

14. Jia, Y., Y. Zhang, S. Wang and A. Raible. 2006. Numerical simulations of channel response to riverine structures in arkansas river. In: Proceeding of the $7^{\text {th }}$ Internatinal Conferance on Hydroscience and Engineering (ICHE-2006), Philadelphia, USA.

15. Khosravi, R. 1391. Numerical Simulation of flow and sediment by CCHE2D Model (case study: downhill minab dam), MSc. Thesis, Hormozgan University. (In Farsi).

16. Malek Abasloo, A., H. Hajikandi and M. Piristani. 1391. Two-dimensional modeling of flow pattern in convective rivers, In: Proceeding of the $9^{\text {th }}$ International Seminar on River Engineering, Shahid Chamran University of Ahvaz. (In Farsi).

17. Malek Abasloo, A., H. Hajikandi, M. Mahmoudi Vanalia and M. Vosough. 1391. Flood zoning in cone-shaped rivers using two-dimensional CCHE2D model, In: Proceeding of the $11^{\text {th }}$ Iranian Hydraulic Conference, Urmia University. (In Farsi).

18. Naderi Fasarani, A., B. Roshanzar, M. Nasiri and Gh. Zahhtabian. 2009. River engineering and operational strategies for correction of flood spreading areas (case study: shahid yaghoubi dam - torbat heydariyeh watershed), In: Proceeding of the $5^{\text {th }}$ National Conference on Watershed Management Science and Engineering, Gorgan University of Agricultural Sciences and Natural Resources. (In Farsi).

19. Naji Abhari, M. 2008. Numerical simulation of flow pattern in 90 degree arc using SSIIM software, In: Proceeding of the $4^{\text {th }}$ National Congress of Civil Engineering, University of Tehran. (In Farsi).

20. Najafipour, F. and A. S. Sakabi. 2006. Design of unstable walled twistways to control the path and reduce sedimentation process, In: Proceeding of the $7^{\text {th }}$ Seminar on River Engineering, Shahid Chamran University of Ahvaz. (In Farsi).

21. Nikro, P., M. Kavianpour and M. Pourhassan. 2011. Investigation of flood damage in cone-stricken rivers using Arc GIS software, In: Proceeding of the $10^{\text {th }}$ Iranian Hydraulic Conferance, Rasht, Iran Hydraulic Society, University of Guilan. (In Farsi).

22. Nicksokhan, M., S. Seif and M. Vosough. 2010. Numerical investigation of flood propagation pattern in taper, In: Proceeding of the $9^{\text {th }}$ Iranian Hydraulic Conference, Tarbiat Modarres University. (In Farsi).

23. Noah, A. 2003. Investigation of geomorphological status of pichanrood and its role in bed and erosion of the minab river, Geographical Research 51: 65-84.

24. Principles of Design of Erosion Control Structures in Rivers and Waterways. 2008. Issue 417. Vice President of Strategic Planning and Supervision.

25. Rinaldi, M., B. Wyz and N. Surian. 2005. Sediment mining in alluvial channels: physical effects and management perspectives, River Research and Applications 21: 805-828.

26. Rostami Moeghbali, S. 2011. Evaluation of the impacts of structures constructed in kordan river cone on morphological and hydraulic changes of branched branch flows. In: Proceeding of the $10^{\text {th }}$ Iranian Hydraulic Conference, University of Guilan. (In Farsi). 
27. Rostami, M. P. and E. Delafrouz. 2009. Influence of principal design of protective structure on changing pattern of flow distribution pattern of hablehroud river in garmsar conic impact area, In: Proceeding of the $8^{\text {th }}$ Iranian Hydraulic Conference, University of Tehran. (In Farsi).

28. Shojaei Fard, M. H. and A. S. Norpour Hashtrood. 2000. Introduction to Computational Fluid Dynamics, Iran University of Science and Technology. (In Farsi).

29. Vafa'i Manesh, M. and H. Khorsandi. 2007. One-dimensional analysis of arterial rivers and their bedding (case study: rudan river), In: Proceeding of the $6^{\text {th }}$ Iranian Hydraulic Conference, Shahrekord University. (In Farsi).

30. Zhang, Y. 2009. CCHE-GUI - Graphical Users Interface for NCCHE Model User's Manual Version 3.0, Technical Report No. NCCHE-TR-2009-01, Mississippi University, MS 38677.

31.Zorkeflee, H. 2007. Application of 2-D modelling for muda river using CCHE2D, In: Proceeding of the International Conference on Managing Rivers in the 21 Century Solution Towards Sustainable River Basins. 


\title{
Numerical Analysis of Hydraulic Flow in a River Alluvial Fan with the CCHE2D \\ (A Case Study: Oregon River between the Sudjan Bridge and Dimeh)
}

\author{
A. Honarbakhsh ${ }^{1}$, M. Fathi ${ }^{2 *}$ and M. Rostami ${ }^{1}$
}

(Received: March 15-2017; Accepted: November 17-2018)

\begin{abstract}
In general, rivers are one of the best and most accessible water resources at the disposal of mankind. So, given the effect of the force of water and changes on the flow patterns and consequently, on river morphology changes, the analysis of the flow in the river is important and necessary to organize projects, flood control and water supply structures downstream. In this study, by using numerical models CCHE2D hydraulic conditions Dimeh River Bridge between Oregon Bridge Sudjan was investigated. CCHE Model is a mathematical model capable of simulating the flow patterns and sediment transport in rivers and canals laboratory network. The numerical model in 1998, based on the calculations by the National Centre for Water Science and Engineering, University of Mississippi (NCCHE), was developed and has been applied in many research projects related to water engineering. At the outset, the input data required model provides and numerical model was implemented. In the next step, the results of the model were calibrated and validated using field data measurements; eventually, they were extracted and their model results were compared; it was confirmed that CCHE model could still simulate the flow pattern.
\end{abstract}

Keywords: CCHE Model and Validation, Flow Pattern, Morphology, River

1. Faculty of Natural Resources and Earth Sciences, University of Shahrekord, Shahrekord, Iran.

2. Soil Conservation and Watershed Management Research Institute, Tehran, Iran.

*: Corresponding Author, Email: fathiapadana@gmail.com 